\title{
Cooling history of Atlantis Bank oceanic core complex: Evidence for hydrothermal activity 2.6 Ma off axis
}

\author{
Joshua J. Schwartz \\ Department of Geology and Geophysics, University of Wyoming, Laramie, Wyoming 82071, USA \\ Now at Department of Geological Sciences, University of Alabama, Tuscaloosa, Alabama 35487, USA \\ (joshua.j.schwartz@gmail.com) \\ Barbara E. John and Michael J. Cheadle \\ Department of Geology and Geophysics, University of Wyoming, Laramie, Wyoming 82071, USA \\ Peter W. Reiners \\ Department of Geosciences, University of Arizona, Tucson, Arizona 85721, USA
}

\section{A. Graham Baines \\ Research Centre for Tectonics, Resources and Exploration, School of Earth and Environmental Sciences, University of Adelaide, Adelaide, South Australia 5005, Australia}

[1] We report 26 (U-Th)/He zircon ages from Atlantis Bank, Southwest Indian Ridge, which constrain time scales and rates of lower crustal cooling in ultraslow spreading oceanic crust in this setting. Samples from the detachment fault surface indicate that denuded oceanic crust cooled rapidly $(<1 \mathrm{Ma})$, yielding cooling rates $>1200^{\circ} \mathrm{C} / \mathrm{Ma}$, consistent with existing models for the cooling of oceanic crust. (U-Th)/He zircon ages from samples collected along $\mathrm{N}-\mathrm{S}$ and $\mathrm{E}-\mathrm{W}$ trending faults scarps record young ages inconsistent with standard cooling models for lower oceanic crust. These samples have a mean (U-Th)/He zircon age 2.6 Ma younger than their corresponding igneous crystallization ages and record cooling through $200^{\circ} \mathrm{C}$ well outside the rift valley. Similar anomalously young ages are recorded by zircon, sphene, and apatite fission track data from ODP Hole 735B. We interpret these young ages as recording an off-axis thermal/heating event associated with localized high-temperature $\left(>300^{\circ} \mathrm{C}\right)$ hydrothermal fluid flow resulting from underplated mafic magmas.

Components: 15,168 words, 13 figures, 3 tables.

Keywords: core complex; thermochronology; geochronology.

Index Terms: 1036 Geochemistry: Magma chamber processes (3618); 1140 Geochronology: Thermochronology; 8424 Volcanology: Hydrothermal systems (0450, 1034, 3017, 3616, 4832, 8135).

Received 3 March 2009; Revised 22 June 2009; Accepted 29 June 2009; Published 28 August 2009.

Schwartz, J. J., B. E. John, M. J. Cheadle, P. W. Reiners, and A. G. Baines (2009), Cooling history of Atlantis Bank oceanic core complex: Evidence for hydrothermal activity 2.6 Ma off axis, Geochem. Geophys. Geosyst., 10, Q08020, doi:10.1029/ 2009GC002466. 


\section{Introduction}

[2] Magmatism in mid-ocean ridge environments is one of the primary mechanisms by which the Earth transfers heat from its interior to the surface. Much of the thermal energy released during the crystallization of magmas at mid-ocean ridges is transferred to the hydrosphere by conduction; however, convective hydrothermal circulation accounts for as much as one third of the total heat loss during cooling of oceanic crust [e.g., Humphris et al., 1995; German and Von Damm, 2003; German and Lin, 2004]. Rates and time scales for the cooling of oceanic crust have been estimated from numerical models [e.g., Maclennan et al., 2005], geothermometry of Ca exchange between olivine and clinopyroxene in ophiolitic and in situ oceanic crust [Coogan et al., 2002, 2007], inversions of seismic velocity data [e.g., Dunn et al., 2000], and geochronology and thermochronology of cored crustal sections [e.g., John et al., 2004]. In slow spreading mid-ocean ridge environments, difficulties in estimating rates and time scales of cooling are compounded by complex magmatic/ tectonic processes including episodic versus continuous magmatic accretion [e.g., Maclennan et al., 2005], high-angle normal faulting [e.g., Tucholke and Lin, 1994; Small, 1998; Buck et al., 2005], lowangle detachment faulting [e.g., Cann et al., 1997; Tucholke et al., 1998; MacLeod et al., 2002; IODP Expeditions 304 and 305 Scientists, 2005], and heterogeneous hydrothermal circulation along these features [Fisher and Becker, 2000; Wetzel et al., 2001; Coogan et al., 2007; McCaig et al., 2007]. To surmount these difficulties, numerical models for the thermal and mechanical evolution of oceanic crust (including oceanic detachment faults) [e.g., Lavier et al., 1999, 2000; Buck et al., 2005] require direct observational constraints of the thermal structure of lower oceanic crust through time.

[3] The purpose of this paper is to investigate the cooling history over a broad region of crust exposed in the footwall of an oceanic core complex. Specifically, we present geochronometric and thermochronometric data for samples collected from both the seafloor and from ODP Hole $735 \mathrm{~B}$ at Atlantis Bank, south of the slow to ultraslow spreading Southwest Indian Ridge (Figure 1). We use (U-Th)/He zircon cooling ages together with existing $\mathrm{Pb} / \mathrm{U}$ zircon ages [John et al., 2004; Schwartz et al., 2005; Baines et al., 2008], magnetic anomaly data [Baines et al., 2008], biotite ${ }^{40} \mathrm{Ar} /{ }^{39} \mathrm{Ar}$, and sphene, zircon and apatite fission track ages [John et al., 2004] to document the thermal history of Atlantis Bank, and to place constraints on the role of faulting and hydrothermal circulation in its development. Our results suggest that Atlantis Bank experienced rapid initial cooling $\left(\sim 800^{\circ} \mathrm{C}\right.$ in $500 \mathrm{ka}$ after igneous crystallization), which likely took place during detachment faulting associated with core complex formation. This rapid cooling history is overprinted by a subsequent thermal event as revealed by anomalously young zircon and titanite fission track ages (closure temperature $\left.\left(\mathrm{T}_{\mathrm{c}}\right)=\sim 365-280\right),(\mathrm{U}-\mathrm{Th}) / \mathrm{He}$ ages $\left(\mathrm{T}_{\mathrm{c}}=\right.$ $\left.\sim 200^{\circ} \mathrm{C}\right)$, and apatite fission track ages $\left(\mathrm{T}_{\mathrm{c}}=\right.$ $\sim 110^{\circ} \mathrm{C}$ ). These young ages cannot be explained by simple models which assume conductive and convective cooling near the ridge axis, but instead argue for an off-axis heating event significantly outside the rift valley. We explore possible thermal sources for this off-axis heating event; all of which require significant advection of heat by hydrothermal activity along fault zones. Possible heat sources include: exothermic serpentinization of the underlying mantle, and/or underplating by off-axis basaltic magmatism due to transtension along the adjacent Atlantis II transform fault.

\section{Geology of Atlantis Bank}

[4] The Southwest Indian Ridge (SWIR) is a transitional slow to ultraslow spreading mid-ocean ridge [Dick et al., 1991b, 2003], which separates the Antarctic and Indian plates (Figure 1, inset). The average Antarctic plate spreading half rate is estimated at $8.6 \mathrm{~km} / \mathrm{Ma}$ since $\sim 19 \mathrm{Ma}$ [Dick et al., 1991b; Hosford et al., 2003; Baines et al., 2008]. Atlantis Bank lies approximately $100 \mathrm{~km}$ south of the SWIR rift valley and, Baines et al. [2008] estimated an anomalously fast seafloor halfspreading rate of $14.1+1.9 /-1.6 \mathrm{~km} / \mathrm{Ma}$ during slip on the detachment fault that bounds the Atlantis Bank core complex.

[5] On the basis of drilling, dredging, manned submersible and ROV observations, Atlantis Bank comprises variably deformed and denuded lower oceanic crust and upper mantle [Cannat et al., 1991; Dick et al., 1991a, 2000; Natland and Dick, 2002]. Rocks from ODP Holes 735B and 1105A and submersible dives at Atlantis Bank include olivine gabbro, olivine gabbronorite, and oxide gabbro with minor felsic veins [Dick et al., 1991a; Pettigrew et al., 1999; Dick et al., 2000; Robinson et al., 2000; Arai et al., 2001; Kinoshita et al., 2001; Natland and Dick, 2001; Matsumoto et al., 2002; Natland and Dick, 2002]. Oxide 


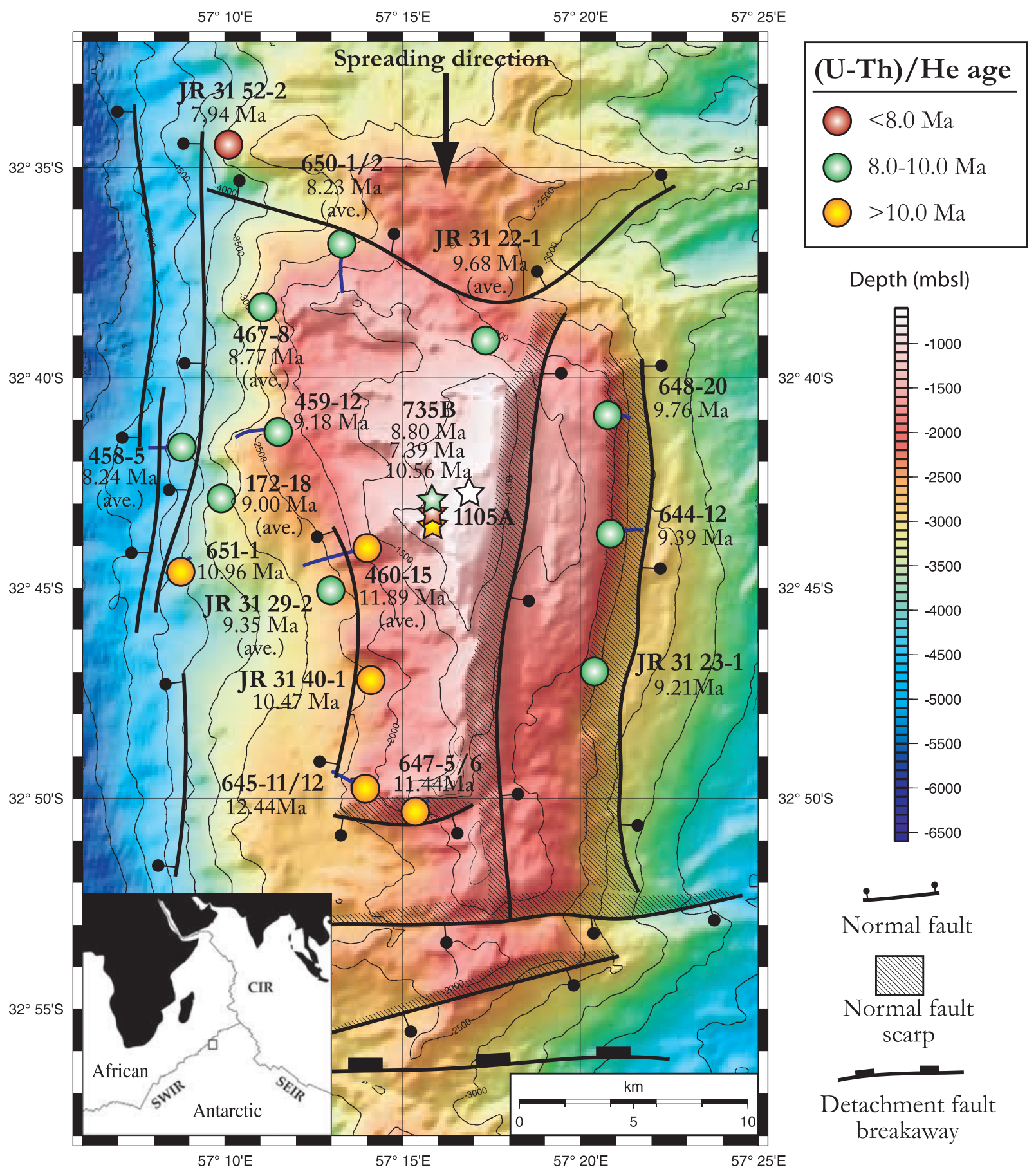

Figure 1. Bathymetric map of Atlantis Bank depicting locations of samples selected for (U-Th)/He zircon age determinations. Samples collected by manned submersible and dredging are shown as circles; samples from ODP Holes 735B and 1105A are shown as stars. Dive tracks are shown in solid blue lines. Major faults and fault scarps are superimposed on bathymetry. (U-Th)/He zircon ages are given adjacent to sample locations. In general, older (U-Th)/ He zircon ages are concentrated near the center of core complex, and younger ages are located along fault scarps on the flanks of Atlantis Bank. Spreading direction is north to south. SWIR, SEIR, and CIR refer to Southwest Indian Ridge, Southeast Indian Ridge, and Central Indian Ridge.

gabbros and felsic veins comprise $\sim 24 \%$ of ODP Hole $735 \mathrm{~B}$ and commonly host trace minerals (e.g., apatite, zircon, and titanite) suitable for geochronologic and thermochrologic dating [John et al., 2004]. $\mathrm{Pb} / \mathrm{U}$ geochronologic ages from Atlantis Bank range from 10.80 to $14.00 \mathrm{Ma}$ [John et al., 2004; Schwartz et al., 2005; Baines et al., 2008], although some anomalously old ages may 


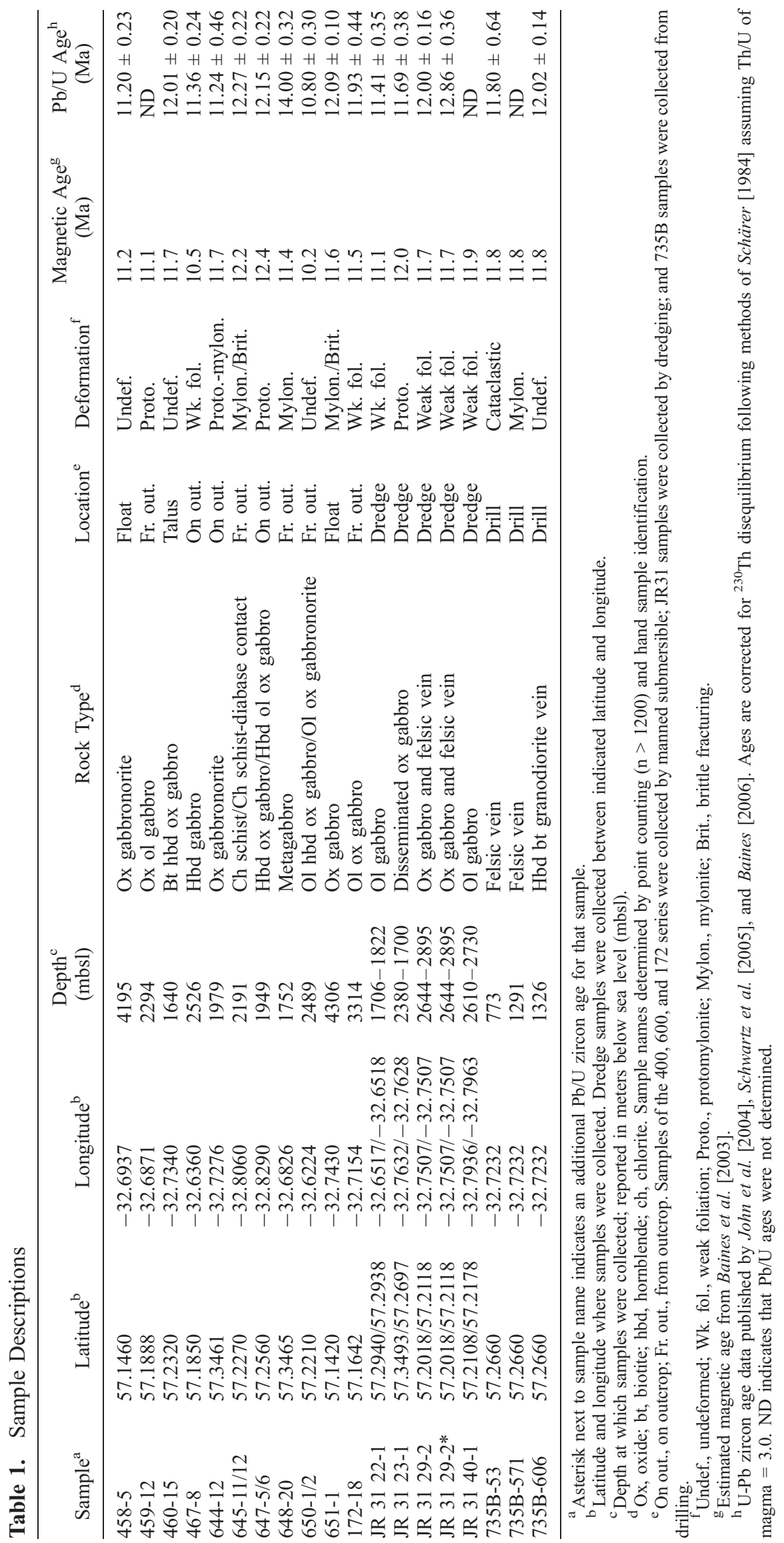




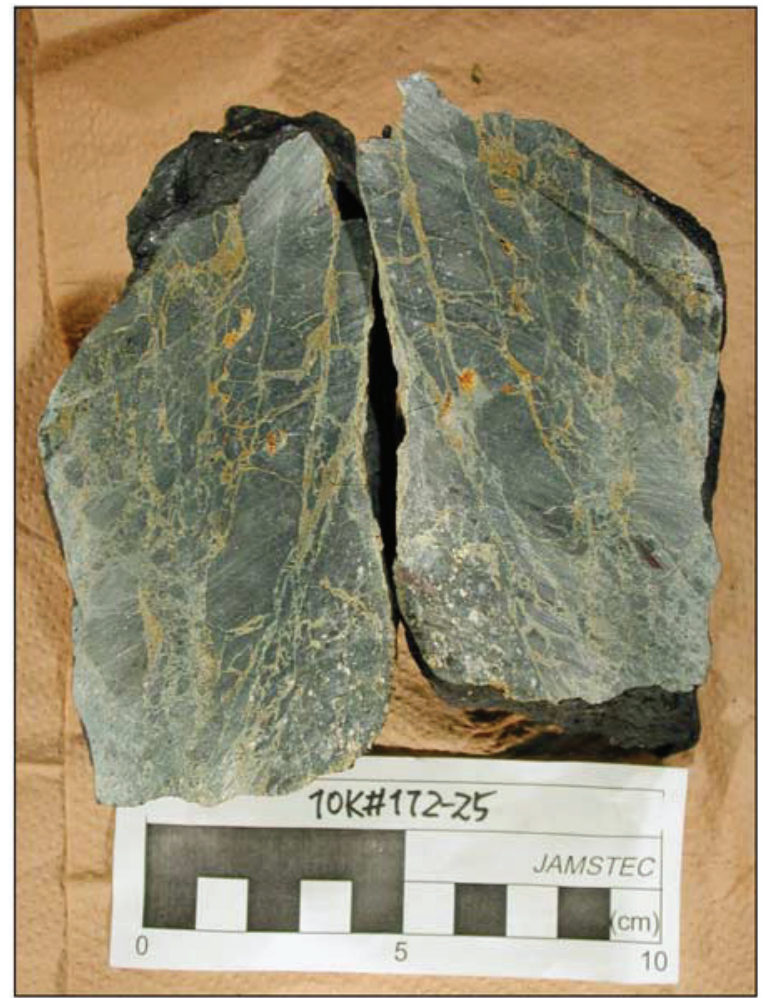

Figure 2. Photograph of sample 172-25, an oxide gabbro mylonite, collected from a $\mathrm{N}-\mathrm{S}$ striking fault along the western flank of Atlantis Bank. The sample shows extensive brittle deformation with associated epidote-filled fractures and is interpreted to have been altered to greenschist facies minerals by hydrothermal upflow along the fault plane (sampled at $3041 \mathrm{mbsl}$ [Arai et al., 2001]).

reflect assimilation of preexisting gabbroic rocks or zircon xenocrysts from the deeper lithosphere [Schwartz et al., 2005]. Previous $\mathrm{Pb} / \mathrm{U}$ zircon ages are summarized in Table 1.

[6] Structurally, Atlantis Bank forms the footwall of a long-lived detachment fault system that likely rooted beneath the rift valley and is inferred to be responsible for the tectonic removal of $1.5-2.0 \mathrm{~km}$ of upper crust during oceanic core complex development [Vanko and Stakes, 1991; Dick et al., 2000; Kelley and Früh-Green, 2001]. At Atlantis Bank, the smooth, dome-shaped detachment fault surface characteristic of young oceanic core complexes is dissected by both transform-parallel $(\mathrm{N}-\mathrm{S})$ and transform-perpendicular $(\mathrm{E}-\mathrm{W})$ fault systems (Figure 1), interpreted to be associated with flexural uplift resulting from regional transtension between $\sim 19.5$ and $7.5 \mathrm{Ma}$ [Baines et al., 2003]. These faults are easily recognized on bathymetric maps as moderately dipping slopes with scarps showing tens to hundreds of meters of relief. On the basis of estimated magnetic anomaly ages, the transform-parallel and transform-perpendicular faults that define Atlantis Bank deform crust as young as $\sim 9.3 \mathrm{Ma}$ (chron C4Ar) [Baines et al., 2007], placing a maximum age on the timing of fault movement (i.e., post 9.3 Ma).

[7] The largest of the scarps include two moderately dipping $\left(30^{\circ}-50^{\circ}\right)$ transform-parallel faults on the eastern flank of Atlantis Bank, that extend for more than $25 \mathrm{~km}$ along strike and truncate the detachment fault surface, suggesting hundreds of meters of throw after cessation of detachment fault slip (Figure 1). The upper and lower scarps have $\sim 600 \mathrm{~m}$ and $1200 \mathrm{~m}$ of bathymetric relief, respectively [Baines et al., 2003]. Manned submersible dives to the lower of these scarps (Shinkai 6500 dives 644 and 648) observed striae and shingle structure that confirm down-to-the-east, normal sense motion on the fault system that creates this scarp [Matsumoto et al., 2002]. On dive 644, a 100-m-high section of fault scarp was observed with striae that rake $\sim 85^{\circ}$ to the north, indicating a small sinistral component to the dominantly dipslip motion.

[8] Observations from the west flank of Atlantis Bank indicate nearly pure dip-slip motion on $\mathrm{N}-\mathrm{S}$ striking scarps, tens to a few hundreds of meters high, that dip $40^{\circ}-60^{\circ}$ west [Kinoshita et al., 2001]. High-resolution multibeam bathymetry and manned submersible dive observations suggest that original $100-\mathrm{m}$-scale fault scarps cutting the serpentinized and altered peridotite basement have been dissected and obscured by extensive slump scars and debris flows. Observations from Kaiko Dive 172 indicate that massive exposures of oxide gabbro below the detachment fault surface (3040 mbsl), are cut by steeply dipping E-W and $\mathrm{N}-\mathrm{S}$ oriented joints and normal and strike-slip faults [Arai et al., 2001]. Deformation fabrics in oriented samples from these outcrops indicate a significant history of brittle deformation crosscut or synchronous with high-temperature hydrothermal alteration (including epidote-cemented breccia and cataclasite (Figure 2)).

[9] Fault rocks associated with movement on the detachment fault exposed at the seafloor around Atlantis Bank include mylonites and ultramylonites, overprinted by extensively altered cataclasites, locally ultracataclasites, and rare gouge. Nearly continuous core from ODP Holes 735B and $1105 \mathrm{~A}$ (located $1.2 \mathrm{~km} \mathrm{NE}$ of 735B [Pettigrew et al., 1999; Casey and Miller, 2007]) demonstrate that the detachment fault zone is characterized by 
development of mylonitic fabrics within the upper $100 \mathrm{~m}$ of the Hole [Cannat et al., 1991; Dick et al., 2000]. Core from Hole 735B exhibits magmatic and metamorphic fabrics ranging down-temperature from submagmatic, granulite $\left(650^{\circ}-900^{\circ} \mathrm{C}\right)$, amphibolite $\left(450^{\circ}-650^{\circ} \mathrm{C}\right)$, greenschist $\left(300^{\circ}-\right.$ $450^{\circ} \mathrm{C}$ ) and subgreenschist grades [Cannat et al., 1991; Dick et al., 2000; Miranda, 2006]. Microstructural and mineral thermometry indicate deformation initiated at high temperatures $\left(>900^{\circ} \mathrm{C}\right)$ in the ductile regime [Mehl and Hirth, 2008], and continued to lower temperatures through the semibrittle and brittle regimes as fault rocks were denuded along the detachment fault system [Miranda, 2006]. The semibrittle greenschist grade overprint of gabbro mylonites from seafloor exposures of the fault records the subsequent lowertemperature history; chlorite thermometry records deformation from $\sim 250^{\circ}$ to $350^{\circ} \mathrm{C}$ [Miranda, 2006]. The estimated plate spreading rate during formation of Atlantis Bank [Baines et al., 2008], together with the width of the modern rift valley [Hosford et al., 2003], suggests that active slip (and associated hydrothermal circulation) on the detachment fault system ceased as the footwall emerged at the rift valley wall, and was denuded to the seafloor, approximately $500 \mathrm{ka}$ after formation.

[10] Postdeformation metamorphic and hydrothermal veins in ODP Holes 735B and 1105A indicate that postcrystallization hydrothermal alteration extensively overprinted the upper $500-600 \mathrm{~m}$ of the section, with less abundant veining and fluid alteration of deeper structural levels [Robinson et al., 1991; Stakes et al., 1991; Vanko and Stakes, 1991; Bach et al., 2001; Alt et al., 2002; Alt and Bach, 2006; Gao et al., 2006]. Both late stage magmatic and hydrothermal veins functioned as pathways for extensive hydrothermal fluid flow over time [Robinson et al., 2002]. Nearly all high-temperature $\left(>800^{\circ} \mathrm{C}\right)$ metamorphic veins are overprinted by intense hydrothermal alteration at temperatures between $300^{\circ}$ and $600^{\circ} \mathrm{C}$ [Robinson et al., 2002]. High-temperature amphibole veins are restricted to the upper $600 \mathrm{~m}$ of Hole 735B, and amphibole + plagioclase veins are primarily present between 550 and 950 mbsf. Diopside and diopside + plagioclase veins are particularly abundant in the top $400 \mathrm{~m}$, but also occur in clusters between 460 and $750 \mathrm{mbsf}$. Isotopic and fluid inclusion studies of these veins indicate that they were primarily derived by seawater interaction with the host rock at moderate temperatures [Robinson et al., 1991; Stakes et al., 1991; Vanko and Stakes, 1991; Robinson et al.,
2002; Alt and Bach, 2006], but may also have formed from serpentinization reactions [Vanko and Stakes, 1991]. Although the timing of metamorphic and hydrothermal veining is not well known, veins are observed associated with brittle fractures and crosscut preexisting high-temperature deformation fabrics [Robinson et al., 1991; Stakes et al., 1991; Vanko and Stakes, 1991; Robinson et al., 2002; Alt and Bach, 2006]. The generation of these veins is poorly understood and may be related to a number of mechanisms including (1) downward cracking fronts, (2) exothermic serpentinization reactions, and/or (3) off-axis magmatism. We evaluate these models in section 6 in light of new and existing thermchronologic results.

\section{Methods and Model Description}

\subsection{Sample Preparation}

[11] In order to determine the cooling history of lower oceanic crust exposed on Atlantis Bank, we selected 19 zircon-bearing samples for (U-Th)/He age dating. Sample locations are shown in map view in Figure 1. The sampling spans approximately $26 \mathrm{~km}$ parallel $(\mathrm{N}-\mathrm{S})$ and $20 \mathrm{~km}$ perpendicular $(\mathrm{E}-\mathrm{W})$ to the spreading direction. Analyzed samples were collected by manned submersible and ROV dives during JAMSTEC MODE 1998 leg 4, MODE 2000, leg 6 and MODE 2001 Leg 14 cruises, by dredging during RRS James Clark Ross Leg 31, and by drilling from ODP Hole 735B [Allerton and MacLeod, 1998; Arai et al., 2001; Kinoshita et al., 2001; Matsumoto et al., 2002; Natland and Dick, 2002]. Samples were chosen on the basis of the presence of zircon. Detailed rock descriptions are provided by Kinoshita et al. [2001], Arai et al. [2001], Matsumoto et al. [2002], and Dick et al. [1999], and are summarized in Appendix A. The presence of zircon in each sample was confirmed by optical examination in thin section. Because of small sample size (typically $<0.1 \mathrm{~kg}$ ) and potential for contamination, samples were hand-crushed and processed utilizing standard heavy liquid and magnetic separation techniques. Zircon yield ranged from tens to thousands of grains with sizes varying from $<50$ to several hundred microns in length.

\section{2. (U-Th)/He Methods}

[12] The (U-Th)/He thermochronometer is based on the $\alpha$ decay of the parent isotopes ${ }^{238} \mathrm{U},{ }^{235} \mathrm{U}$ and ${ }^{232} \mathrm{Th}$ (and to a lesser extent ${ }^{147} \mathrm{Sm}$ ), to daughter ${ }^{4} \mathrm{He}$. Retention of ${ }^{4} \mathrm{He}$ in the zircon crystal is a function of the stopping distance of the $\alpha$ particle 
during decay $(\sim 15-20 \mu \mathrm{m}$ for zircon), initial distribution of $U$ and Th within the crystal, grain size (surface area to volume ratio), thermally controlled He diffusion rates, and the amount of time spent at elevated temperature conditions. For $\alpha$ decay events that occur near crystal rims, ${ }^{4} \mathrm{He}$ may be ejected from the crystal, resulting in anomalously low daughter/parent ratios along grain boundaries, and correspondingly "young" bulk crystal ages. This $\alpha$ ejection bias is a function of the surface area to volume ratio of the grain and can be corrected by measurement of the geometry of the zircon and by knowledge (or more commonly, assumption) of $\mathrm{U}$ and $\mathrm{Th}$ distribution within and outside the crystal [e.g., Farley et al., 1996]. Because the magnitude of the $\alpha$ ejection correction increases with decreasing grain size (i.e., high surface area to volume ratios), zircons greater than $30 \mu \mathrm{m}$ in $\mathrm{c}$ axis perpendicular half-width are considered most reliable from this standpoint. In most cases, $\alpha$ ejection corrections are applied assuming a homogenous distribution of $U$ and Th. This assumption is clearly not always valid in natural zircons and is a significant source of error in the (U-Th)/He zircon system [Hourigan et al., 2005]. Although analytical precision of measured $\mathrm{U}$, Th and He isotopic ratios is typically $<2 \%$, zircons of known age yield an average reproducibility of $\sim 9 \%(2 \sigma)$ [Reiners, 2005].

[13] Closure temperatures for the (U-Th)/He zircon system are dependent on grain size, cooling rate and diffusion parameters specific to $\mathrm{He}$ in zircon (cf. Dodson [1973] for a general treatment of closure temperature). Diffusion parameters for $\mathrm{He}$ in several types of zircon were experimentally determined by Reiners et al. [2004], yielding a nominal closure temperature of $\sim 180^{\circ} \mathrm{C}$ for effective grain radius of $60 \mu \mathrm{m}$ and a cooling rate of $10^{\circ} \mathrm{C} / \mathrm{Ma}$. There is some evidence that anisotropic diffusion and radiation damage at low extents of damage (e.g., young zircons) may complicate $\mathrm{He}$ diffusion kinetics [Farley, 2007; P. W. Reiners, unpublished data, 2009]), but these effects are likely to have a minor effect on the closure properties in this study, especially for the high cooling rates consistent with the young ages discussed here. Although cooling rates at mid-ocean ridges are poorly constrained, calculated and predicted cooling rates for lower oceanic crust range from $\sim 10^{10} \mathrm{C} / \mathrm{Ma}$ to $10^{4 \circ} \mathrm{C} / \mathrm{Ma}$ depending on the temperature range investigated [Coogan et al., 2002; John et al., 2004; Maclennan et al., 2005]. For low-temperature thermochronometers $\left(<400^{\circ} \mathrm{C}\right)$, cooling rates average $<10^{2 \circ} \mathrm{C} / \mathrm{Ma}[\mathrm{John}$ et al,
2004]. With a cooling rate of $100^{\circ} \mathrm{C} / \mathrm{Ma}$, we calculate closure temperatures for zircon of $203^{\circ} \mathrm{C}$ assuming diffusion parameters of Reiners et al. [2004] and effective grain radius of $50 \mu \mathrm{m}$ (similar to the mean radius of grains analyzed in this study). An average closure temperature of $\sim 200 \pm 15^{\circ} \mathrm{C}$ is used in the following presentation of results and discussion, whereby the error is largely a function of uncertainties in cooling rate.

[14] (U-Th)/He age determinations were performed on individual, euhedral $\geq 50 \mu \mathrm{m}$ diameter, zircon crystals (see Figure 3) wrapped in $\mathrm{Nb}$ foil. He was extracted by Nd-YAG laser heating and measured on a stable isotope quadropole mass spectrometer. $\mathrm{U}$ and Th isotopic compositions were determined by Parr bomb dissolution and solution ICP-MS [Reiners, 2005]. Ages were determined at Yale University laboratory and closely follow procedures described by Reiners [2005]. Raw (U-Th)/ $\mathrm{He}$ ages for all samples were corrected for the effects of alpha ejection using the approach of Farley et al. [1996] and Reiners [2005], modified for the tetragonal prism morphology and density of zircon [Reiners, 2005]. This approach assumes a homogenous distribution of $U$ and Th throughout the zircon crystal, which is an adequate assumption in most cases since typical oceanic zircons display weak chemical variations in backscattered electron and cathodoluminescence images (Figure 3). In some cases, grains were extracted from preexisting ion probe mounts and dated. Because these grains were polished prior to (U-Th)/He dating, their resultant geometries require a slight modification to tetragonal prism morphology typically used in alpha ejection correction described above [Reiners et al., 2007]. These zircons were not previously analyzed for $\mathrm{Pb} / \mathrm{U}$ geochronology prior to extraction from the ion probe mounts. All (U-Th)/He ages are given errors of $9 \%$ on the basis of $2 \sigma$ reproducibility of a standard of known age, unless otherwise noted.

\subsection{Description of Thermal Models}

[15] In order to evaluate the thermochonologic data, we use analytical plate cooling models [McKenzie, 1967] and a simple numerical 2-D finite difference model to calculate cooling profiles for various cooling history scenarios [John et al., 2004]. In these models, we use a full-spreading rate of $14 \mathrm{~mm} / \mathrm{a}$, an off-axis lithospheric thickness of $100 \mathrm{~km}$, a mantle potential temperature of $1330^{\circ} \mathrm{C}$, thermal conductivity of $3.2 \mathrm{~W} / \mathrm{m} / \mathrm{K}$, density of $3300 \mathrm{~kg} / \mathrm{m}^{3}$ and specific heat capacity 


\section{Rapid Cooling Profiles}
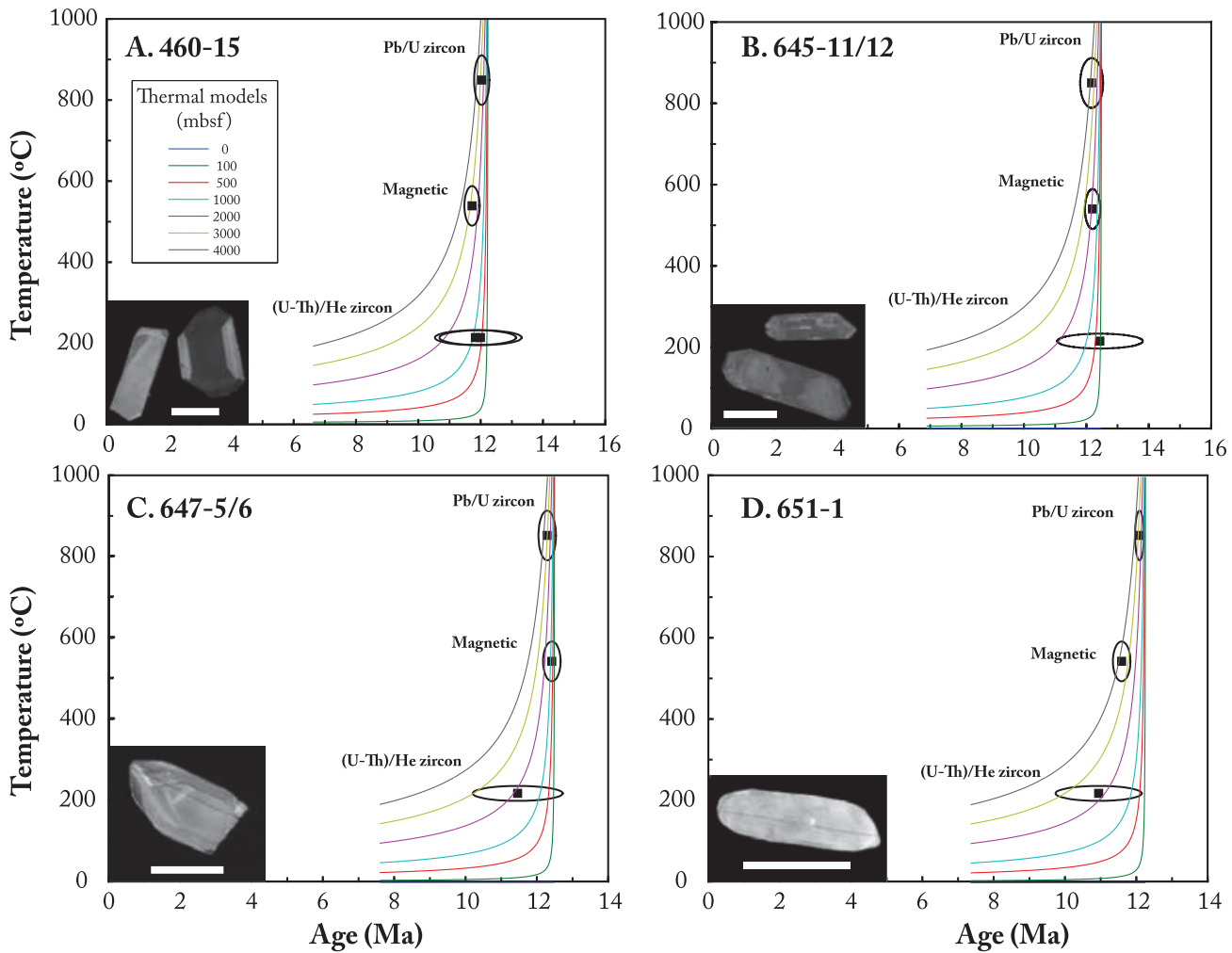

Figure 3. Cooling profiles for samples collected on Atlantis Bank. (a-d) Samples with relatively rapid cooling profiles and (e-1) slower cooling profiles. Thermal models for conductive cooling of oceanic lithosphere at various constant depths are shown by colored curves. Model cooling curves were calculated using a full-spreading rate of $14 \mathrm{~mm} / \mathrm{a}$, a lithospheric thickness of $100 \mathrm{~km}$, a mantle potential temperature of $1330^{\circ} \mathrm{C}$, thermal conductivity of $3.2 \mathrm{~W} / \mathrm{m} / \mathrm{K}$, density of $3300 \mathrm{~kg} / \mathrm{m}^{3}$, and specific heat capacity of $1170 \mathrm{~J} / \mathrm{kg} / \mathrm{K}$. Cathodoluminescence images for each sample, with $100 \mu \mathrm{m}$ scale bars. Note the weak oscillatory and sector zoning for these zircons. U and Th concentrations for zircons analyzed in this study range from $\sim 4$ to $445 \mathrm{ppm}$ and $\sim 2$ to $275 \mathrm{ppm}$, respectively.

of $1170 \mathrm{~J} / \mathrm{kg} / \mathrm{K}$. In Figures $3 \mathrm{a}-31$ we show simple cooling profiles calculated using the plate-cooling model, for depths below the seafloor from 0 to $4000 \mathrm{~m}$. We use these curves to provide a frame of reference for interpreting the data. These curves do not include the effect of denudation by detachment faulting and overestimate the steady state temperature of the crust, as they do not take account of the broad-scale cooling effect of any hydrothermal circulation. Hence, these curves provide maximum estimates for the steady state temperature structure and minimum estimates of cooling rates for a given depth.

[16] We use the 2-D finite difference models to calculate the cooling profiles for Figure 4. This model simulates conductive cooling of the lithosphere, the effects of tectonic unroofing by detachment faulting and the effect of conductive heating due to off-axis magmatism. Detachment faulting is simulated by progressively removing $2.0 \mathrm{~km}$ of crust from the top of the model during the first $0.9 \mathrm{Ma}$ of the cooling history. Off-axis magmatism is simulated by intruding a $2.0-\mathrm{km}$-thick sill at $1.8 \mathrm{~km}$ depth at 9.5 Ma. More detailed descriptions of this plate cooling model are given by John et al. [2004]. This model does not account for hydrothermal circulation at the ridge axis, and simplifies the thermal effects of the intrusion of magma at the ridge axis, and hence the cooling curves provide minimum estimates of cooling rates. However, the model does permit understanding of the major elements of the thermal history recorded by the data. A more complicated model is not used simply because the problem is relatively poorly constrained.

\section{Results}

\section{1. (U-Th)/He Thermochronologic Data}

[17] A total of 26 zircon grains were analyzed from 19 samples for (U-Th)/He age determinations. 


\section{Slow Cooling Profiles}
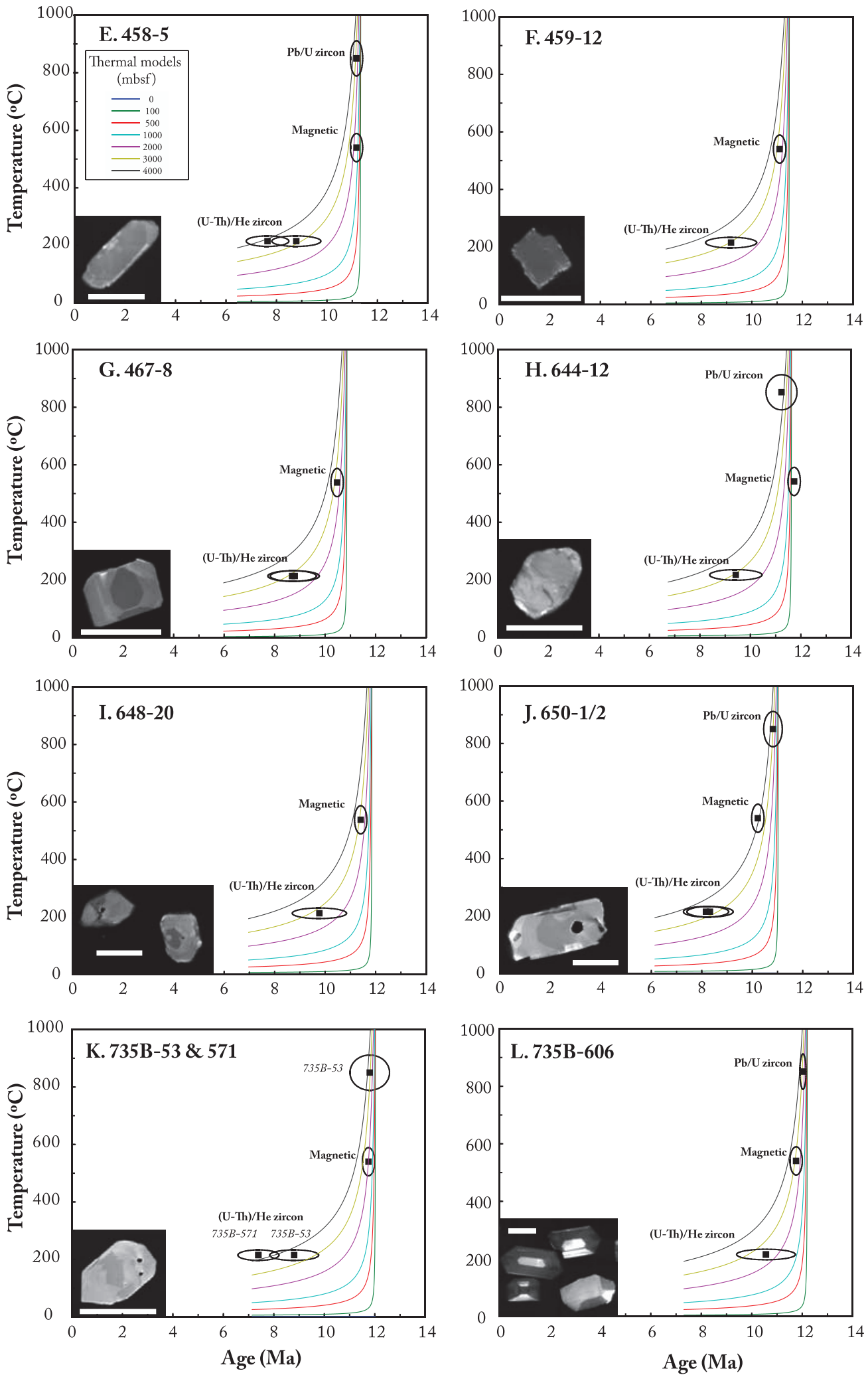

Figure 3. (continued) 


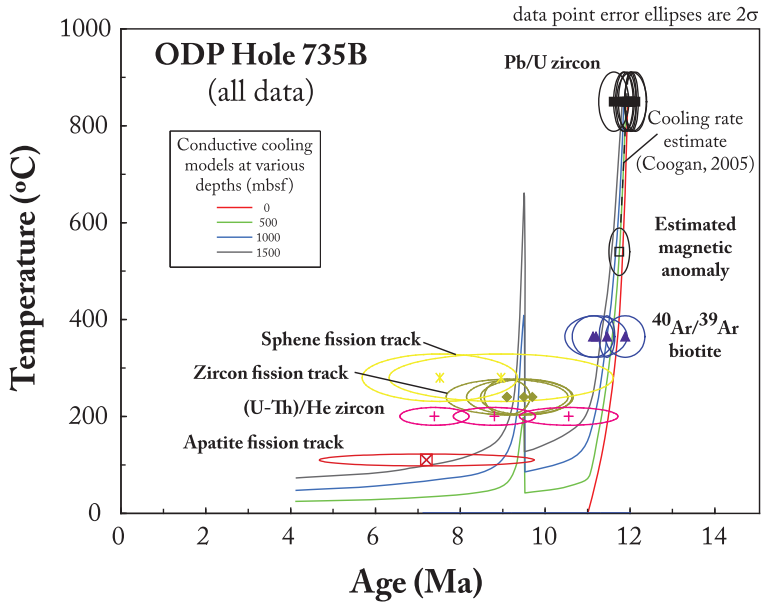

Figure 4. Time-temperature plot for all thermochronologic data from ODP Hole 735B. A thermal model which incorporates effects of detachment faulting is shown for reference. Note that ${ }^{206} \mathrm{~Pb} /{ }^{238} \mathrm{U}$ zircon, estimated magnetic anomaly, and ${ }^{40} \mathrm{Ar}{ }^{39} \mathrm{Ar}$ biotite ages indicate rapid cooling through $\sim 365^{\circ} \mathrm{C}$ and are well described by the detachment faulting thermal model. Lower-temperature $\left(<300^{\circ} \mathrm{C}\right)$ thermochronologic data display relatively young ages that are not consistent with the thermal model and diverge from the early, rapid cooling path. These lower-temperature thermochronology data can be accounted for by a thermal perturbation (mafic underplating) at 9.5 Ma. Colored contours represent different conductive cooling depths. Advection of heat by hydrothermal circulation is not accounted for by these models. Cooling rate estimates from Coogan [2005] for temperatures between $600^{\circ} \mathrm{C}$ and $900^{\circ} \mathrm{C}$ are shown as a dashed line.

Multiple grains from a single sample were dated in some cases, and those ages are reported as averaged values. For samples which had zircons dated by U-Pb zircon geochronology [John et al., 2004; Schwartz et al., 2005; Baines et al., 2008, 2009], we plot ${ }^{206} \mathrm{~Pb} /{ }^{238} \mathrm{U}$ zircon crystallization ages together with estimated magnetic anomaly ages [Baines et al., 2008] and (U-Th)/He ages on time-temperature plots (Figures 3a-31, 4-6, and A1). Representative cathodoluminescence images of zircons from these samples are shown together with the geochronologic and thermochronologic data. Where available (e.g., ODP Hole 735B), we also plot these data with existing thermochronologic data including biotite ${ }^{40} \mathrm{Ar} /{ }^{39} \mathrm{Ar}$ ages, and sphene, zircon and apatite fission track ages [John et al., 2004] (Figure 5). We use estimated closure temperatures for magnetic anomalies (i.e., magnetite Curie temperature), the ${ }^{40} \mathrm{Ar} /{ }^{39} \mathrm{Ar}$ biotite and sphene, zircon and apatite fission track systems of $\sim 540 \pm 40^{\circ} \mathrm{C}, 365 \pm 35^{\circ} \mathrm{C}, 280 \pm 30^{\circ} \mathrm{C}, 240 \pm$ $30^{\circ} \mathrm{C}$, and $110 \pm 10^{\circ} \mathrm{C}$, respectively (for closure temperature references see John et al. [2004]). Some samples from Atlantis Bank have anomalously old $\mathrm{Pb} / \mathrm{U}$ zircon ages, which record a precrustal formation event [Schwartz et al., 2005]; consequently, those old ages are not included in time-temperature cooling profiles.

[18] Thermochronologic results from Atlantis Bank yield (U-Th)/He zircon ages ranging from $7.4 \mathrm{Ma}$ to $12.4 \mathrm{Ma}$ (Figure 1 and Table 2). In general, we observe older $(\mathrm{U}-\mathrm{Th}) / \mathrm{He}$ ages $(<1.2 \mathrm{Ma}$ younger than the $\mathrm{Pb} / \mathrm{U}$ age) in the $\mathrm{SW}$ quadrant of Atlantis Bank associated with samples collected directly from the detachment fault surface, whereas younger ages $(>1.2 \mathrm{Ma}$ younger than the $\mathrm{Pb} / \mathrm{U}$ age) occur in samples from ODP Hole 735B, and along the flanks where the core complex has been dissected by later faults that truncate the detachment surface (Figure 7). In the following presentation of results, we first discuss thermochronologic results from ODP Hole 735B, and then we discuss (U-Th)/ He ages from surface samples exposed along Atlantis Bank.

\subsection{ODP Hole 735B}

[19] (U-Th)/He data from ODP Hole 735B are plotted in Figures 3-5 with other geochronologic and thermochronologic data. These samples span nearly $1400 \mathrm{~m}$ depth below seafloor (mbsf), from 53 to 1430 mbsf. In these samples, the hightemperature thermal history of ODP Hole $735 \mathrm{~B}$ is recorded by $\mathrm{Pb} / \mathrm{U}$ zircon ages which give a weighted average crystallization age of $11.99 \pm 0.05 \mathrm{Ma}$ [Baines et al., 2009]. Cooling through intermediate temperatures $\left(\sim 540-365^{\circ} \mathrm{C}\right)$ is indicated by the estimated magnetic anomaly age of $11.8 \pm 0.2 \mathrm{Ma}$ [Baines et al., 2008], and the weighted average of biotite ${ }^{40} \mathrm{Ar} /{ }^{39} \mathrm{Ar}$ data of $11.46 \pm 0.35 \mathrm{Ma}$ [John et al., 2004].

[20] The lower-temperature $\left(<360^{\circ} \mathrm{C}\right)$ thermal history of ODP Hole $735 \mathrm{~B}$ appears to be more protracted and spans at least 3-4 Ma after initial igneous crystallization (see Figures 4 and 5). Samples from 279 to $606 \mathrm{mbsf}$ yield titanite fission track ages $\left(\mathrm{T}_{\mathrm{c}}=280 \pm 30^{\circ} \mathrm{C}\right)$ of $7.4 \pm 1.8 \mathrm{Ma}$ and $9.1 \pm 2.6 \mathrm{Ma}(2 \sigma[\mathrm{J}$ ohn et al., 2004]). Four zircon fission track ages $\left(\mathrm{T}_{\mathrm{c}}=240 \pm 30^{\circ} \mathrm{C}\right)$ from depths of 571 to 996 mbsf record a recalculated weighted mean age of $9.2 \pm 0.5 \mathrm{Ma}$. Three $(\mathrm{U}-\mathrm{Th}) / \mathrm{He}$ zircon ages $\left(\mathrm{T}_{\mathrm{c}}=200 \pm 15^{\circ} \mathrm{C}\right)$ from the top $606 \mathrm{~m}$ of the Hole display ages of $8.80 \pm 0.70 \mathrm{Ma}, 7.39 \pm$ $0.59 \mathrm{Ma}$ and $10.56 \pm 0.95 \mathrm{Ma}$ (Figures 3e-31). The weighted mean age of these (U-Th)/He ages is $8.6 \pm 3.8 \mathrm{Ma}$. Two of these ages occur at depths of 


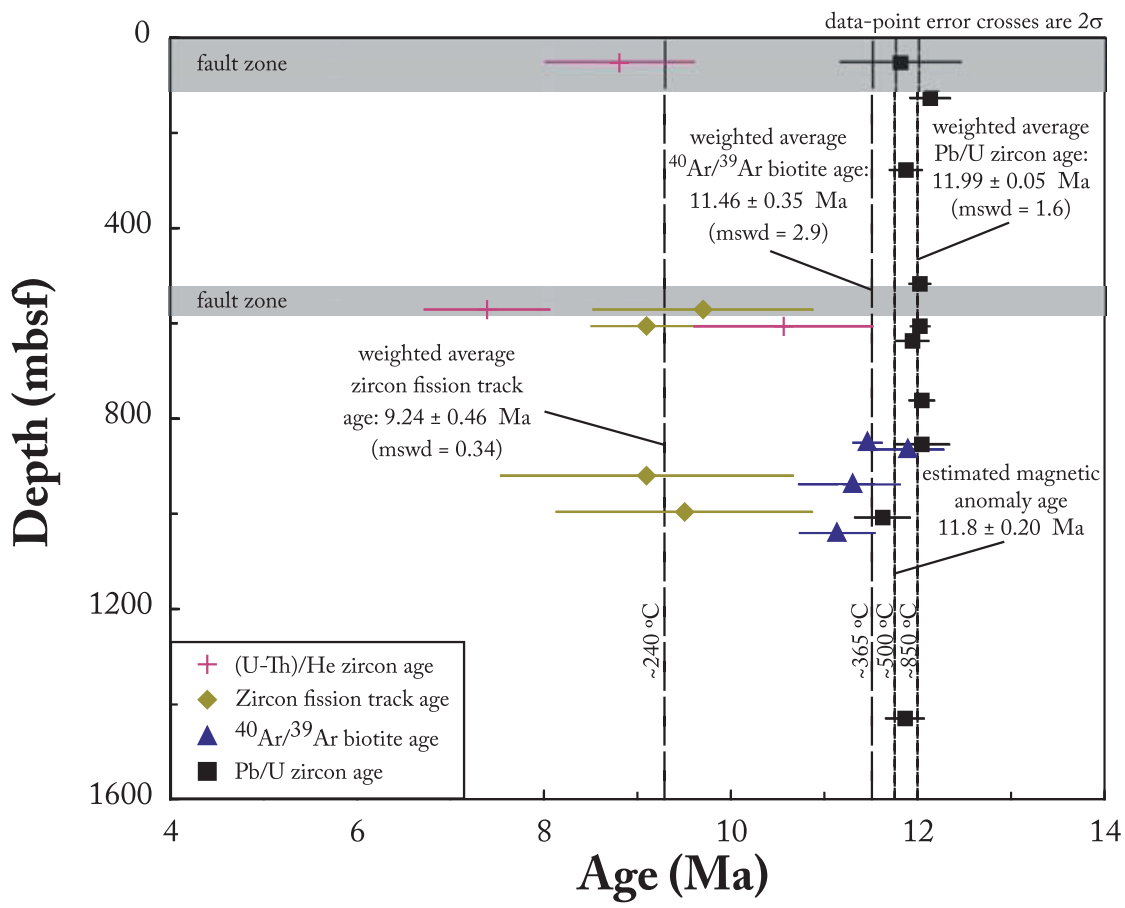

Figure 5. Age versus depth for selected data from ODP Hole 735B. Weighted average ages for geochronologic and thermochronologic data are shown by dashed lines with approximate closure temperatures indicated along vertical lines. Note that data from 735B indicate rapid cooling through $\sim 365^{\circ} \mathrm{C}$, followed by a protracted cooling history involving thermochronologic ages as much as 4.5 Ma younger than the weighted average crystallization age of Hole 735B. These young ages are inconsistent with simple conductive cooling models.

53 and $571 \mathrm{mbsf}$, and are from structurally disrupted, cataclastic and mylonitic shear zones. Finally, an apatite fission track age of $7.2 \pm 2.6 \mathrm{Ma}$ at $1077 \mathrm{mbsf}$ indicates very slow cooling though its closure temperature of $\sim 110^{\circ} \mathrm{C}$. It should be noted that theoretically, the low-temperature ages should decrease downhole by $\sim 0.5$ Ma per $\mathrm{km}$, as a consequence of expected slower cooling rates with depth. Unfortunately, such a decrease is smaller than the errors associated with the data and is therefore not resolvable.

\subsection{Seafloor Samples: Western Flank}

[21] Samples from the western flank of Atlantis Bank are divided into two groups on the basis of their cooling histories. Samples that cooled rapidly have $(\mathrm{U}-\mathrm{Th}) / \mathrm{He}$ zircon ages less than $1.2 \mathrm{Ma}$ younger than their $\mathrm{Pb} / \mathrm{U}$ ages (yellow circles, Figure 7); whereas samples with more protracted cooling histories have (U-Th)/He zircon ages greater than 1.2 Ma younger than their $\mathrm{Pb} / \mathrm{U}$ ages (green circles, Figure 7). The rapidly cooled samples are found in the southwestern quadrant of Atlantis Bank. From north to south, the rapidly cooled samples include 460-15, 651-1, 645-11/12, and 647-5/6. All of these samples display similar, rapid cooling profiles (from high-temperature crystalli- zation through lower-temperature conditions, $\sim 200^{\circ} \mathrm{C}$; Figures $3 \mathrm{a}-3 \mathrm{~d}$ ). The weighted average zircon $\mathrm{Pb} / \mathrm{U}$ age minus the zircon (U-Th)/He age of these samples is $\sim 0.5 \mathrm{Ma}$, implying a mean cooling rate from igneous crystallization temperatures down to $\sim 200^{\circ} \mathrm{C}$ of $\sim 1200^{\circ} \mathrm{C} / \mathrm{Ma}$ for these samples (assuming igneous crystallization of zircons at $850^{\circ} \mathrm{C}$ [Grimes et al., 2007]). Three of the four samples that record rapid cooling are located away from the later intermediate dip faults that cut the detachment surface. Samples 645-11/12 and 651-1 were sampled from the detachment fault and are extensively altered in association with high-temperature mylonitic, and lower-temperature semibrittle to brittle deformation. Sample 460-15 is not deformed, is unaltered, and may be an undeformed phacoid enveloped by faults/ shear zones within the detachment fault system. The fourth sample, 647-5/6, is protomylonitic and was collected from an E-W trending fault scarp.

[22] Five samples with from the northwestern quadrant have both $\mathrm{Pb} / \mathrm{U}$ zircon ages and (U-Th)/ He zircon ages, which give slow cooling profiles. They were recovered at or along moderately dipping fault surfaces and display young (U-Th)/He zircon dates ranging from $7.94 \pm 0.71 \mathrm{Ma}$ to $9.68 \pm$ $0.87 \mathrm{Ma}(650-1 / 2$, JR 31 22-1, 458-5, 172-18, and 


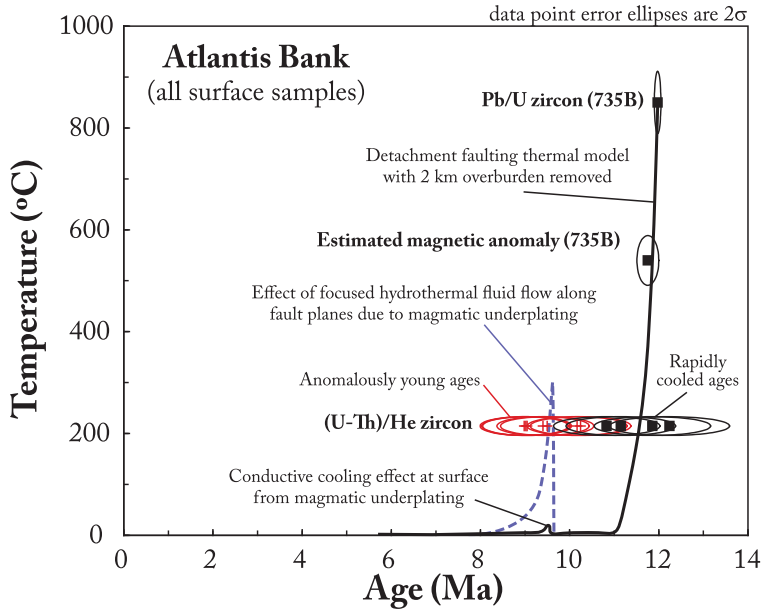

(Standardized to $\mathrm{Pb} / \mathrm{U}$ crystallization age of $735 \mathrm{~B}$ )

Figure 6. Time-temperature plot for all surface samples from Atlantis Bank. (U-Th)/He zircon ages are standardized to the weighted average $\mathrm{Pb} / \mathrm{U}$ zircon crystallization age of ODP Hole 735B [Baines et al., 2009]. See section 5 for standardization calculation equation. A thermal model which incorporates effects of detachment faulting is shown for reference. Ages shown in black are consistent with simple conductive cooling; however, ages in red are not within error of conductive cooling. Note that the older (U-Th)/He zircon ages are well described by the detachment faulting thermal model, but younger samples are too young relative to the model. Conductive cooling and hydrothermal effects resulting from a mafic underplating event at 9.5 Ma are shown by black (solid) and blue (dashed) thermal perturbations.

JR 31 29-2 (Figures $3 \mathrm{e}-31$ and A1)). The weighted average age for these samples is $8.72 \pm$ $0.51(\mathrm{mswd}=2.4)$. These samples have $(\mathrm{U}-\mathrm{Th}) / \mathrm{He}$ zircon cooling ages between 2.6 and $3.0 \mathrm{Ma}$ younger than their respective $\mathrm{Pb} / \mathrm{U}$ crystallization ages. All samples with slow cooling profiles also show extensive postcrystallization greenschist facies alteration of primary igneous minerals (Table 3). For example, in sample 172-18, there is a diffuse boundary between relatively fresh and highly altered oxide gabbro with actinolite pseudomorphing brown igneous hornblende (Figure 8). Large igneous zircon in the altered region are fractured and in filled with green actinolite (Figure 8), indicating the association of brittle fracturing with greenschist facies alteration.

\subsection{Seafloor Samples: Eastern Flank}

[23] Along the eastern flank of Atlantis Bank, three samples (JR 31 23-1, 644-12, and 648-20 (Figure 1)) record relatively young (U-Th)/He zircon ages of $9.21 \pm 0.83 \mathrm{Ma}, 9.39 \pm 0.85 \mathrm{Ma}$ and $9.76 \pm 0.88 \mathrm{Ma}$, respectively. Samples 644-12 and JR 31 23-1 have (U-Th)/He zircon ages $1.8 \mathrm{Ma}$ and $2.5 \mathrm{Ma}$ younger than their respective crystallization ages. Sample 648-20 has an anomalously old U-Pb age [Schwartz et al., 2005] and therefore the difference between its crystallization age and (U-Th)/He zircon age is not considered. All of these samples were recovered from a fault scarp with up to $1.2 \mathrm{~km}$ of local relief, and all show extensive (up to 90\%) postcrystallization greenschist facies alteration (Appendix A). Metamorphic assemblages include chlorite, actinolite, hornblende, epidote, serpentine and clay minerals (Table 3 and Appendix A). Thin sections (Figure A2) display pervasive greenschist facies alteration associated with local brittle deformation, which cut obliquely across high-temperature mylonitic fabrics. In sample 648-20, the original high-temperature mylonitic fabric is extensively overprinted by hornblendeactinolite mineralogy, which is in turn cut by veins hosting sphene, magnetite and plagioclase. The extensive alteration exhibited by these samples suggests localized postcrystallization hydrothermal alteration at greenschist facies conditions $\left(300-450^{\circ} \mathrm{C}\right)$ along crosscutting normal faults.

\section{Interpretation of Results}

[24] In order to compare and contrast cooling profiles of these samples (many of which have different crystallization ages), we standardize (U-Th)/He zircon age data to the weighted average crystallization age of ODP Hole 735B (11.99 $\pm 0.05 \mathrm{Ma}$ [Baines et al., 2009]) according to the following equation (see Figure 6):

$$
\begin{aligned}
(\mathrm{U}-\mathrm{Th}) / \mathrm{He}_{(\text {standardized age })}= & (\mathrm{U}-\mathrm{Th}) / \mathrm{He}_{(\text {measured age })} \\
& +\left(\mathrm{Pb} / \mathrm{U}_{(735 \mathrm{~B} \text { age })}-\mathrm{Pb} / \mathrm{U}_{(\text {sample age })}\right)
\end{aligned}
$$

[25] This standardization scheme accounts for differences in the timing of initial igneous crystallization between samples by relating them to a reference value (in this case the age at ODP Hole $735 \mathrm{~B})$. Hence, this method allows us to evaluate the relative cooling rates (e.g., rapid versus slow) on a single summary diagram irrespective of initial crystallization ages (Figures 4 and 6).

\subsection{ODP Hole 735B}

[26] Thermochronologic ages from ODP Hole $735 \mathrm{~B}$ indicate that lower oceanic crust cooled rapidly from high-temperature, crystallization conditions $\left(>850^{\circ} \mathrm{C}\right)$ to $\sim 360^{\circ} \mathrm{C}$ within approximately $500 \mathrm{ka}$ [John et al., 2004]. This rapid and 


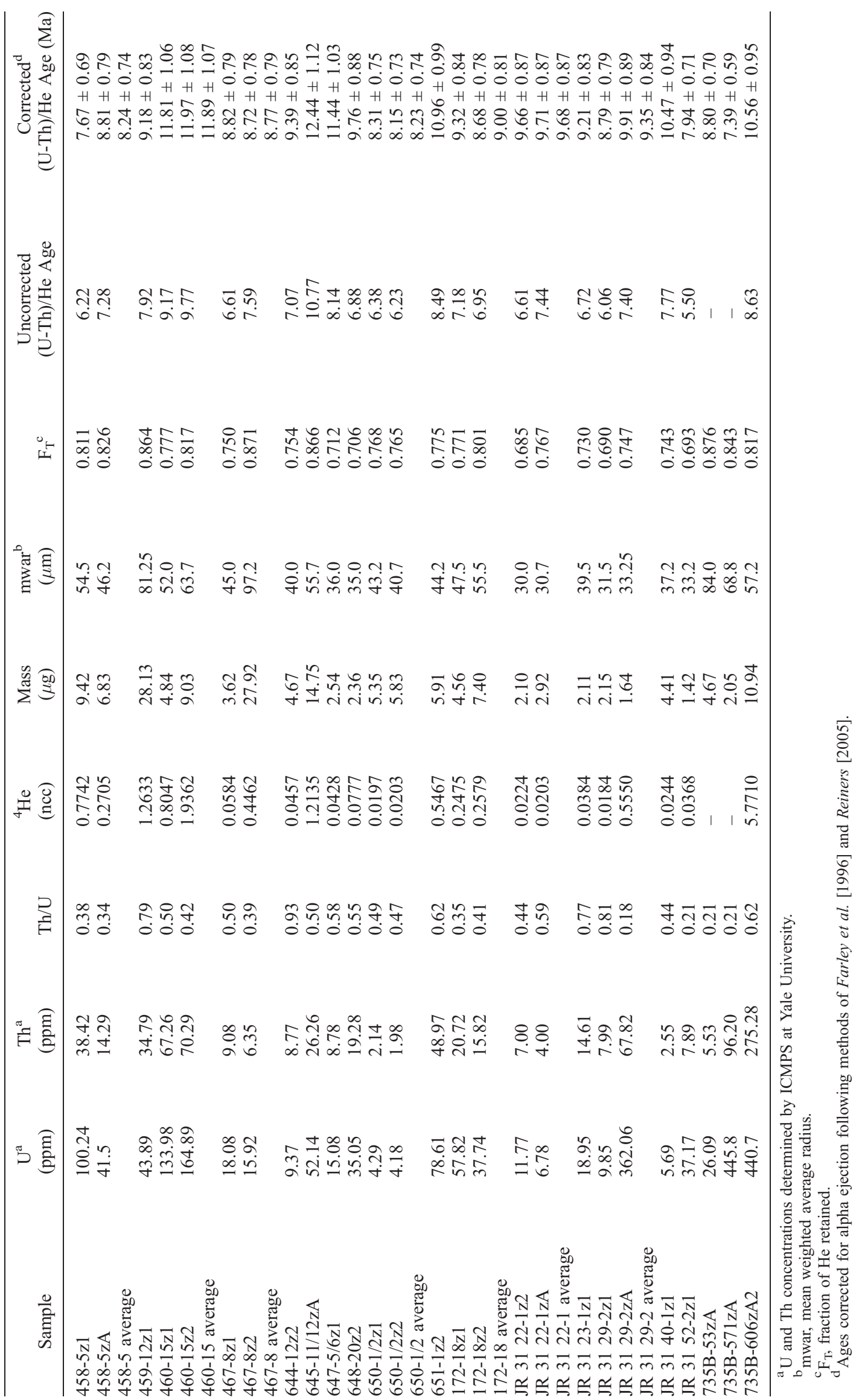




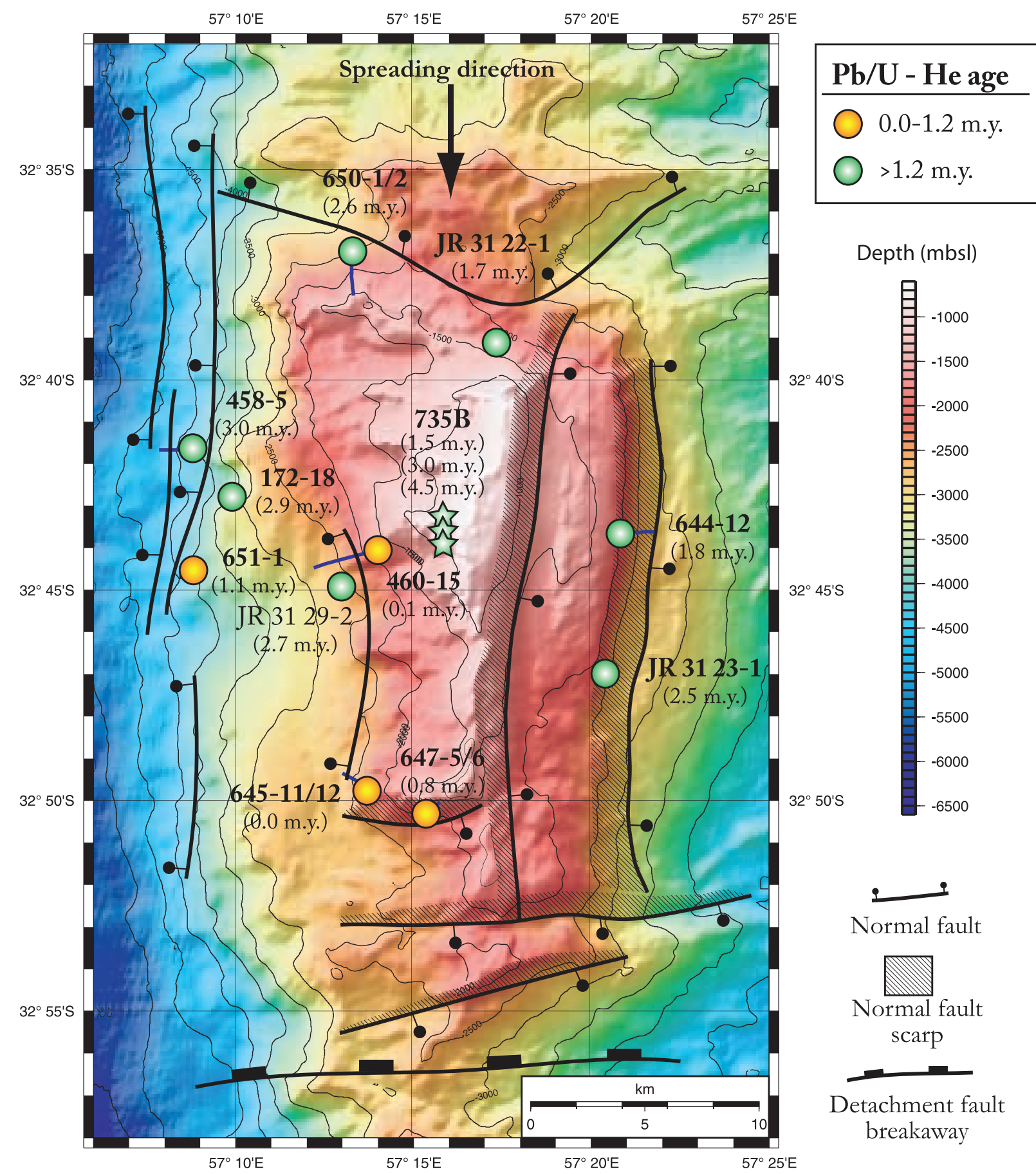

Figure 7. Bathymetric map of Atlantis Bank showing crustal cooling ages (i.e., the difference between $\mathrm{Pb} / \mathrm{U}$ zircon crystallization ages and (U-Th)/He zircon ages). Note that the majority of the crustal cooling ages are $>1.0 \mathrm{Ma}$ and formed well outside the axial rift valley. These results are not predicted by simple conductive cooling thermal models and suggest that these samples were affected by a thermal event. Spreading direction is north to south.

early cooling history is consistent with thermal models [e.g., Maclennan et al., 2005] and Ca-inolivine thermospeedometry [Coogan et al., 2007] for the cooling of lower oceanic crust. In contrast to this result, low-temperature thermochronologic ages from three different minerals (sphene, zircon and apatite) using two thermochronometers (fission track and $(\mathrm{U}-\mathrm{Th}) / \mathrm{He})$ are anomalously young $(\geq 3 \mathrm{Ma}$ younger than the crystallization age of Hole 735B). Although the temperatures of these samples are what one would expect for cooling of samples at $3 \mathrm{~km}$ depth (Figures $3 \mathrm{e}-31$ ); all of these 


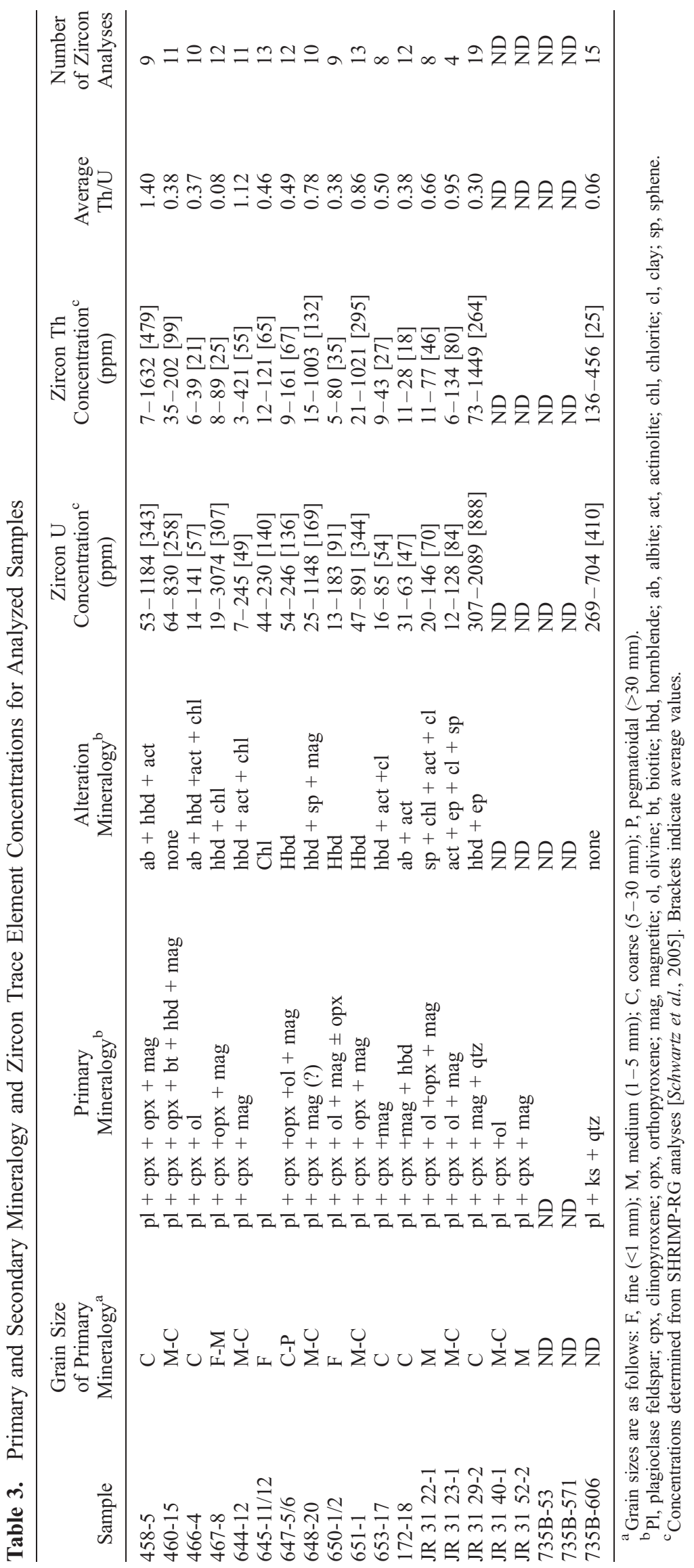




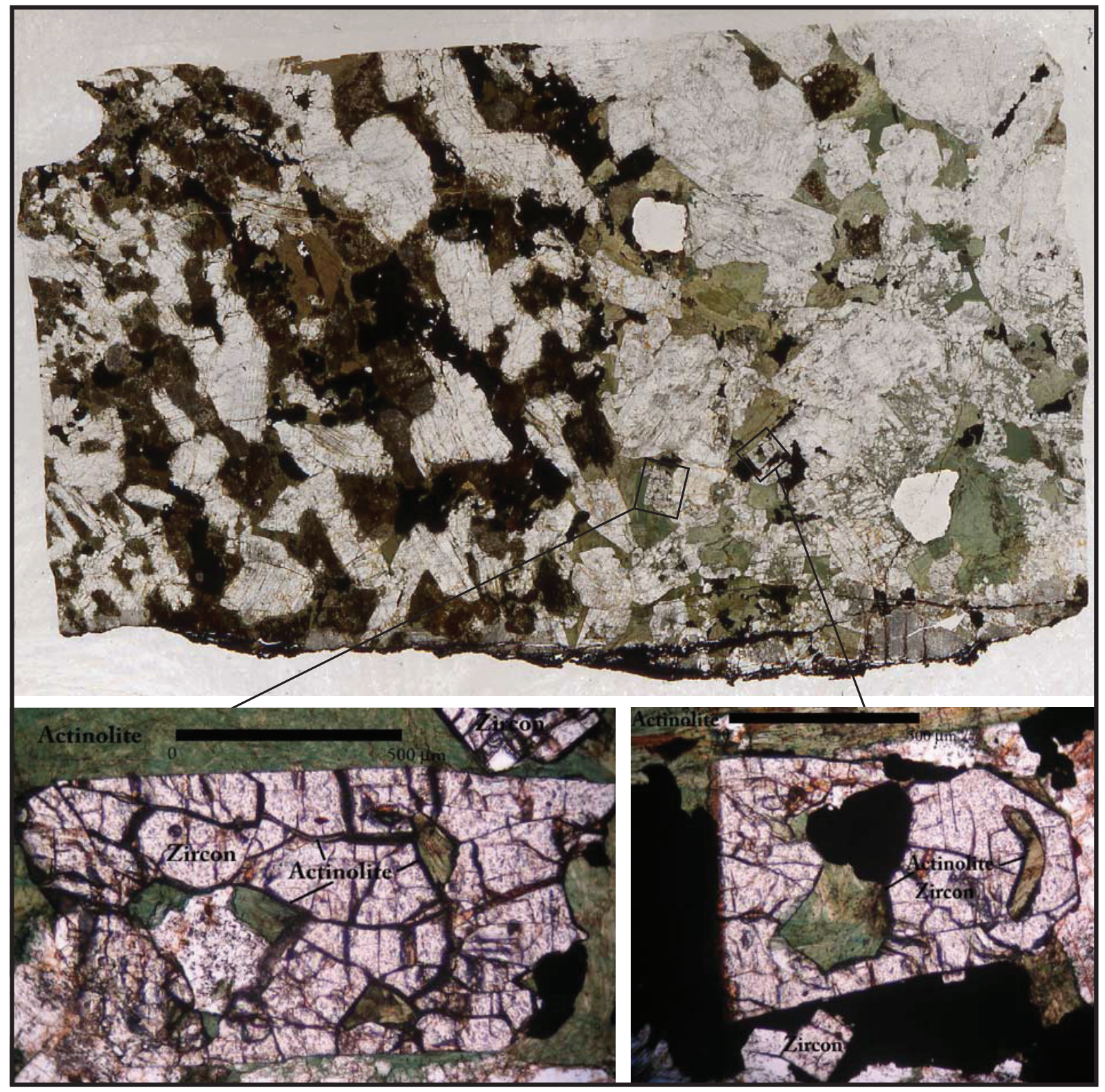

Figure 8. Thin section scan in plain polarized light of sample 172-18b from the western structural domain of Atlantis Bank. Two photomicrographs show fractured zircons infilled with actinolite. Note the greenschist facies alteration front which dissects the thin section (top to bottom).

samples were denuded to much shallower depths $(<1.2 \mathrm{~km})$ by detachment faulting shortly after igneous crystallization. Thus, these samples exhibit "slow" cooling relative to the conductive cooling models (Figure 4), and show a marked departure from the early and rapid, high- to moderate-temperature cooling history of Hole $735 \mathrm{~B}$, which is exhibited by the $\mathrm{Pb} / \mathrm{U}$ zircon, magnetic anomaly and ${ }^{40} \mathrm{Ar} /{ }^{39} \mathrm{Ar}$ biotite data. These low-temperature data are also inconsistent with rapid cooling histories reported from lower oceanic crust [e.g., Coogan et al., 2002, 2006], and from numerical models for the cooling of lower crust [Henstock et al., 1993; Phipps Morgan and Chen, 1993; Maclennan et al., 2005]. Therefore, we suggest that these samples were subject to a process or event, which either (1) held them above their closure temperature well after igneous crystallization or (2) partially or completely reset their lowtemperature ages after early and rapid cooling. In both cases, the addition of heat up to 2-3 Ma after igneous crystallization is necessary to explain these young ages. 
[27] We show cooling curves with a superimposed thermal event, derived using our simple 2-D conductive cooling model, to compare with the data in Figure 4. The majority of the high-temperature and low-temperature thermochronologic data are well described by this model which involves rapid cooling during detachment faulting and removal of $2.0 \mathrm{~km}$ of upper crust, followed by a thermal event (in this case, magmatic underplating) at 9.5 Ma. Temperature variations with initial depth below the seafloor are represented by colored curves and these span the sampled depth range. We suggest the thermal models involving mafic underplating at $9.5 \mathrm{Ma}$ as a likely explanation for the anomalously young low-temperature thermochronologic ages in ODP Hole 735B.

\subsection{Seafloor Samples}

[28] Standardized (U-Th)/He zircon data for all seafloor samples (i.e., not including samples from ODP Hole 735B) are presented in Figure 6. Most of these samples were collected along normal fault scarps and thus were originally located tens to a few hundreds of meters below the detachment fault surface prior to normal faulting. Because these samples are located near to the surface of Atlantis Bank, their depth prior to detachment faulting is assumed to be $\sim 2 \mathrm{~km}$ below seafloor on the basis of fluid inclusions studies from the upper $500 \mathrm{~m}$ of Hole 735B [Kelley and Früh-Green, 2001]. We use the 2-D finite difference thermal model discussed above to interpret the cooling history of these surface samples. The cooling curve generated from this model (Figure 6, heavy black line) assumes that the rocks currently at the seafloor originally crystallized at $2.0 \mathrm{~km}$ depth at the ridge axis, but were then denuded to the near surface by detachment faulting at the rift valley wall. Thus, the curve predicts that samples near the surface of the detachment fault should cool to near $0^{\circ} \mathrm{C}$ as the detachment fault is unroofed. Ages shown by black squares are consistent with this simple conductive cooling model; however, ages shown by red symbols are not within error of the model. The effect of conductive heating due to the thermal event discussed in section 5.1 (i.e., mafic underplating at $1.8 \mathrm{~km}$ bsf) is shown by a small perturbation to the conductive cooling curve at $9.5 \mathrm{Ma}$. This perturbation is small because, the cooling curve was calculated for an initial depth of $2 \mathrm{~km}$ followed by denudation to a few meters below the surface. Once samples are exposed to the surface, their temperature is maintained at $\sim 0^{\circ} \mathrm{C}$ because of their proximity to seawater. The dashed blue curve qualitatively shows the possible additional thermal effect on samples near to the surface if they were affected by short-lived hydrothermal fluid flow along fault planes driven by magmatic underplating at depth.

\subsubsection{Southwestern Flank: Rapidly Cooled Samples}

[29] Rapidly cooled samples from the southwestern flank are well described by the simple conductive cooling model with detachment faulting described above (Figure 6, black ellipses). On the basis of the rapid cooling exhibited by these samples, their fit with our detachment faulting cooling model, and their microstructural and metamorphic features, we interpret these samples as having cooled rapidly in association with core complex formation as the detachment fault emerged from the hanging wall at the rift valley wall. These samples are significant because they suggest that the young (U-Th)/He ages recorded by the remainder of the data set record a later, discrete thermal event, rather than a continuous protracted cooling history (see below). We suggest that it is unlikely that the southwestern part of the core complex would have cooled rapidly while the rest of the core complex cooled slowly. Instead, the entire core complex likely cooled rapidly as it was denuded, and a later thermal event with associated hydrothermal heat advection along fault zones likely reheated/reequilibrated the samples from the northwestern and eastern flanks.

\subsubsection{Eastern Flank: Anomalously Young (U-Th)/He Ages}

[30] Young (U-Th)/He zircon ages located along the eastern flank of Atlantis Bank are inconsistent with the rapid cooling implied by the simple conductive cooling with detachment faulting models described above. Several features suggest that these (U-Th)/He zircon ages were reset during focused high-temperature $\left(300-400^{\circ} \mathrm{C}\right)$ hydrothermal fluid flow along active fault planes. These features include (1) the location of the samples along large-slip fault scarps; (2) the location of some of the samples near to the surface of the seafloor, which requires that temperatures of 300$400^{\circ} \mathrm{C}$ result from advective heat transport and not by conductive heat transport; (3) their pervasive greenschist facies metamorphic overprint; (4) their anomalously young ages relative to the conductive thermal models; and (5) their statistically overlapping ages, which yield a weighted average age of $9.44 \pm 0.48 \mathrm{Ma}(\mathrm{mswd}=0.43)$. Each sample 


\section{W-E Bathymetric Profile for 648-20}

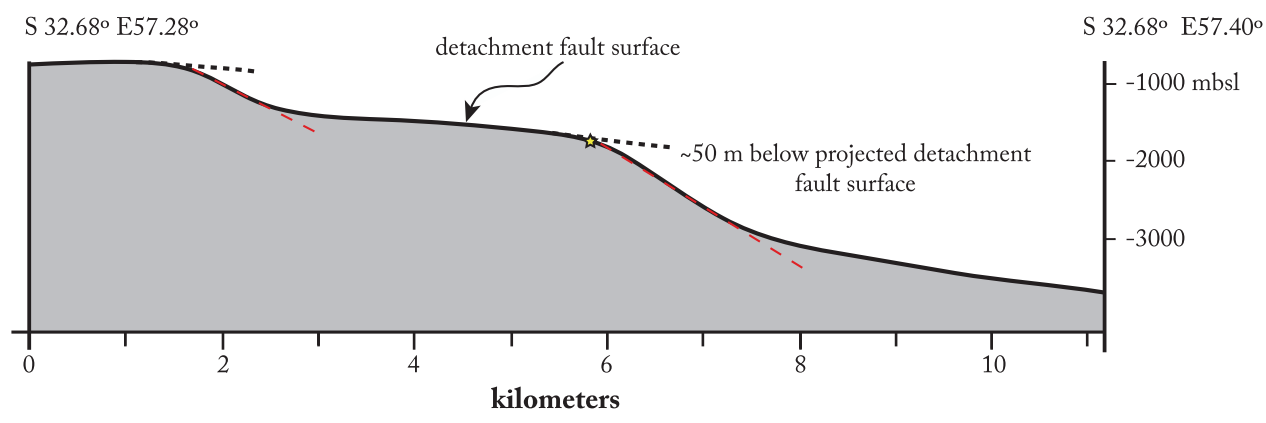

\section{W-E Bathymetric Profile for 644-12}

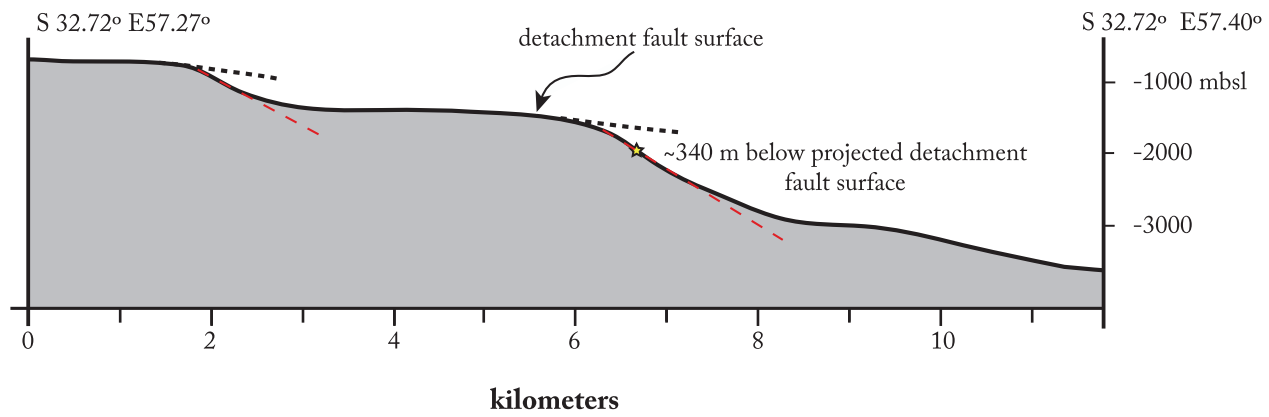

Figure 9. W-E bathymetric profiles across the eastern fault scarp of Atlantis Bank. Sample locations are indicated with yellow stars. In both cases, samples were recovered along gently dipping normal fault surfaces $\left(\sim 30^{\circ}\right.$, shown by dashed red line) and are located at shallow structural levels below the projected detachment fault surface. Thermal models for samples at these shallow structural levels predict rapid cooling $(<1 \mathrm{Ma})$, in contrast to $(\mathrm{U}-\mathrm{Th}) / \mathrm{He}$ zircon dates. Bathymetric profile is oriented perpendicular to spreading direction.

was collected only a few tens to hundreds of meters below the detachment fault surface (e.g., samples 648-20 and 644-12 (Figure 9)), where simple conductive cooling models predict that they would experience rapid cooling through $\sim 200^{\circ} \mathrm{C}$ in less than $1 \mathrm{Ma}$. Therefore, these samples likely underwent an early and rapid cooling history similar to samples from the western flank, but were later affected by an additional thermal event associated with greenschist facies alteration localized along the postdetachment, moderately dipping oblique slip faults shown in Figures 1 and 9.

[31] To quantify the feasibility and potential time scales for greenschist facies hydrothermal fluids to reset the $(\mathrm{U}-\mathrm{Th}) / \mathrm{He}$ zircon system, we use $\mathrm{He}$ diffusion coefficients determined from Arrhenius relationships in experimental studies [Reiners et $a l ., 2004]$ and extrapolate them to greenschist facies conditions $\left(300-400^{\circ} \mathrm{C}\right)$. The fraction of
He loss $(f)$ resulting from a thermal heating event is given by,

$$
f=1-\left(\frac{6}{\pi^{2}}\right) \sum_{1}^{\infty}\left(\frac{1}{n^{2}}\right) \exp \left(-n^{2} \pi^{2} \frac{D t}{a^{2}}\right)
$$

where $D$ is the temperature-dependent diffusivity, $t$ is time and $a$ is the effective diffusion radius (see Crank [1975] for discussion on relationship between fractional approach to final uptake and diffusion coefficients, time and grain size). Following the approach of Reiners et al. [2007], we calculate time scales for complete He loss $(f>$ 0.99 ) of $1.4 \mathrm{ka}$ at $300^{\circ} \mathrm{C}$ and 13.8 a at $400^{\circ} \mathrm{C}$, assuming an effective diffusion radius of $45 \mu \mathrm{m}$ (similar to radii of zircons analyzed in this study (Table 2)). These temperature conditions are similar to those reported from structurally controlled high-temperature hydrothermal vent systems [German and Parson, 1998] and the required 
time scales for resetting are similar to time scales of venting reported from modern hydrothermal fields such as the TAG [Lalou et al., 1990, 1993; Humphris and Cann, 2000] and Rainbow sites [German and Parson, 1998; Cave et al., 2002], which have been active on the 1 to $10 \mathrm{ka}$ time scales. Thus, diffusion calculations for greenschist facies conditions suggest that complete reequilibration/ resetting of the (U-Th)/He zircon system is both feasible and a likely process for producing the observed ages along the eastern fault scarp. We therefore interpret the weighted average (U-Th)/He zircon age of the three samples along the eastern scarp as likely representing a resetting event due to focused hydrothermal fluid flow through enhanced permeability fault rocks at $\sim 9.4 \pm 0.5 \mathrm{Ma}$.

\subsubsection{Northwestern Flank: Anomalously Young (U-Th)/He Ages}

[32] As in the case of the eastern fault scarp, these young (U-Th)/He zircon ages are inconsistent with models for conductive cooling and detachment faulting. The location of these samples along moderately dipping fault zones (Figures 1 and 7), the presence of significant greenschist facies alteration, the anomalously young (U-Th)/He zircon ages relative to conductive cooling models, and the relatively short time scales for diffusive reequilibration of the (U-Th)/He zircon system discussed above, suggest that samples along the northern and western flanks were also affected and likely reset by focused hydrothermal fluid flow at temperatures $>300^{\circ} \mathrm{C}$. In contrast to the eastern fault scarp which shows evidence for a discrete event along a single fault at $\sim 9.4 \mathrm{Ma}$, samples from the western flank yield younger ages (as young as $7.9 \mathrm{Ma}$ ), and are from several different fault systems located closer to the Atlantis II Transform fault. Therefore, hydrothermal circulation along the northwestern flank may have continued to younger periods of time associated with transtension along the Atlantis II transform. Implications for these data are discussed below.

\section{Discussion}

[33] The (U-Th)/He zircon ages reported here together with existing geochronologic and thermochronologic data provide new insights into the cooling history of the oceanic crust at Atlantis Bank. These data from across and with depth within an oceanic core complex form the first comprehensive set of geochronologic and thermochronometric data from an entire oceanic core complex, and provide direct temporal and thermal constraints on mechanical models for cooling and core complex formation in slow spreading mid-oceanic environments [e.g., Lavier et al., 1999, 2000; Buck et al., 2005; Tucholke et al., 2008]. Results from our data indicate that Atlantis Bank experienced rapid cooling $(<500 \mathrm{ka}$ after igneous crystallization), which likely took place during detachment faulting associated with core complex formation. This early and rapid cooling history is locally preserved in areas across the core complex, which have not been extensively affected by later intermediate dip faults and hydrothermal circulation. The calculated mean cooling rate for temperatures between 850 and $200^{\circ} \mathrm{C}$ from standardized (U-Th)/ $\mathrm{He}$ zircon surface samples is $\sim 1200^{\circ} \mathrm{C} / \mathrm{Ma}$ for these samples, consistent with earlier observations by John et al. [2004], Coogan [2005], and Coogan et al. [2007] for Atlantis Bank, other sections of lower oceanic crust exposed in ophiolites (e.g., Oman [Coogan et al., 2002, 2006]), and numerical thermal models [Maclennan et al., 2005].

[34] The most surprising result of this study is identification of anomalously young thermochronometric ages, which make up $>70 \%$ of the (U-Th)/He zircon data set. These samples record thermal resetting on average 2.6 Ma after igneous crystallization. On the basis of seafloor spreading rates during core complex formation $(14 \mathrm{~km} / \mathrm{Ma}$ [Baines et al., 2008]), these anomalously young ages reflect thermal events which occurred well outside the rift valley (on average $\sim 36 \mathrm{~km}$ off-axis compared to the present-day half width of the axial ridge valley of $\sim 4.5 \mathrm{~km}$ ). Therefore, the majority of our data cannot be ascribed to simple cooling near the ridge axis, but instead argue for an off-axis heating event significantly outside the rift valley.

[35] Figure 10 summarizes the (U-Th)/He zircon data in a histogram of "crustal cooling time" versus number of samples analyzed. Here, we define crustal cooling time as the difference between the igneous crystallization age (i.e., the $\mathrm{Pb} / \mathrm{U}$ zircon age) and the timing of cooling/resetting through $200^{\circ} \mathrm{C}$ (i.e., the (U-Th)/He zircon age). During detachment faulting, simple conductive cooling models predict that lower oceanic crustal rocks now at depths $\leq 2 \mathrm{~km}$ will cool rapidly through the $(\mathrm{U}-\mathrm{Th}) / \mathrm{He}$ zircon closure temperature in less than 1.0 Ma after igneous crystallization (Figures 4 and 6). These rapidly cooled samples will therefore plot between 0 and 1.0 Ma in Figure 10. Within this time period, the core complex footwall is expected to emerge from the rift valley $(0.45 \mathrm{Ma}$, 


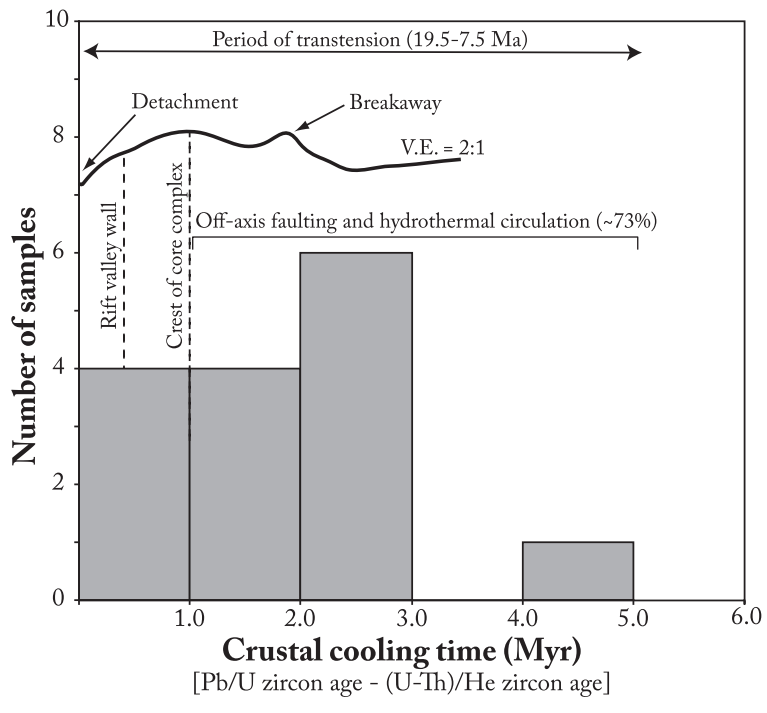

Figure 10. Histogram of crustal cooling time (Ma), defined as the difference in age between igneous crystallization (at $850^{\circ} \mathrm{C}$ ), and cooling through the $(\mathrm{U}-\mathrm{Th}) / \mathrm{He}$ zircon closure temperature $\left(200^{\circ} \mathrm{C}\right)$. A schematic core complex profile (vertical exaggeration $2: 1$ ) is shown above the histogram data and is scaled to show the time when Atlantis Bank emerged from the rift valley (first vertical dashed line), and when it experienced flexural rollover (second vertical dashed line). Thermal models for conductive cooling of lower ocean crust predict that samples will cool in less than $1.0 \mathrm{Ma}$ of igneous crystallization. However, the majority of our data indicate cooling through temperatures of $200^{\circ} \mathrm{C}$, well outside the axial rift valley, and are interpreted to indicate off-axis heating associated with faulting and hydrothermal circulation outside of the axial rift valley.

first dashed line in Figure 10) and will continue to "roll over," with the crest of the core complex being reached approximately $1 \mathrm{Ma}$ off axis (second dashed line in Figure 10) [Lavier et al., 1999]. From studies of young/emergent oceanic core complexes, the majority of brittle deformation and hydrothermal fluid flow associated with detachment faulting occurs within approximately the first million years after igneous crystallization (e.g., Atlantis Massif and $15^{\circ} 45^{\prime} \mathrm{N}$ [Lavier et al., 1999; MacLeod et al., 2002; Blackman et al., 2004; Schroeder and John, 2004; Blackman et al., 2006; Grimes et al., 2008]).

[36] In contrast to the prediction of rapid cooling, we observe that the majority of (U-Th)/He zircon ages record cooling/resetting $>1$ Ma after crystallization, and thus after core complex formation. Many of the samples collected in this study were located along major transform-parallel and transform-perpendicular normal faults, which dissect the core complex. As described above, we interpret the (U-Th)/He zircon ages located along these faults as recording thermal resetting events associated with focused hydrothermal circulation. The timing that these (U-Th)/He zircon ages record also coincides with a period of transtension from 19.5 to 7.5 Ma [Dick et al., 1991b, 1999; Baines et al., 2003], thereby providing a physical mechanism for off-axis brittle faulting on Atlantis Bank. However, the presence of the greenschist facies mineral assemblages associated with mean (U-Th)/He zircon and fission track ages nearly $3 \mathrm{Ma}$ off axis requires a mechanism to provide heat to these young samples tens of kilometers outside the rift valley. Below we evaluate possible mechanisms to provide this off-axis heat.

\subsection{Cracking Fronts and Hydrothermal Circulation Mining Lithospheric Heat}

[37] Cooling models for lower oceanic crust in fast spreading mid-ocean ridge environments suggest that fracturing may begin as a downward propagating "cracking front" in which cooling and fracturing occur at the boundary layer between hot rocks and circulating fluids [Lister, 1974, 1983; Manning et al., 2000]. As the cracking front develops, it mines heat from the surrounding rocks driving high-temperature hydrothermal circulation. On the basis of observations of samples from ODP Hole 735B, Mével and Cannat [1991] noted that the distribution of cracks and hydrothermal veins in the top $500 \mathrm{~m}$ is not consistent with a simple cracking front model. More recent studies of the distribution of cracks and hydrothermal veins over the entire length of ODP Hole 735B [e.g., Robinson et al., 2002; Alt and Bach, 2006] also do not support a simple cracking front model. Instead, these studies indicate that hydrothermal circulation was localized in discrete zones in the upper 700-900 m of Hole 735B [e.g., Robinson et al., 2002], and did not significantly penetrate deeper portions of the lower crust. These results are supported by downhole oxygen isotopic studies, which show relatively unaltered isotopic compositions below 600 m [Alt and Bach, 2006; Gao et al., 2006], also inconsistent with a cracking front model.

\subsection{Serpentinization Reactions}

[38] Possible evidence for hydrothermal venting and exothermic serpentinization reactions on Atlantis Bank is recorded in fluid inclusion data 
which contain trace amounts of methane [Vanko and Stakes, 1991], which may have formed as the by-product of serpentinization reactions [Vanko and Stakes, 1991]. Although evidence for methane may suggest the involvement of serpentinization reactions, fluid temperatures $\left(40-70^{\circ} \mathrm{C}\right.$ at the surface, up to $225^{\circ} \mathrm{C}$ at depth [Kelley and Früh-Green, 2001; Früh-Green et al., 2003]) from modern ultramafic-hosted hydrothermal vents such as the Lost City require time scales of $\sim 275 \mathrm{ka}$ (assuming a $45 \mu \mathrm{m}$ effective diffusion radius at $225^{\circ} \mathrm{C}$ ) to completely reset the (U-Th)/He zircon system. These time scales are much greater than those observed even in long-lived ultramafic hosted vent systems ( 30 ka [Früh-Green et al., 2003]). In addition, some studies of high-temperature hydrothermal vent systems at the Rainbow hydrothermal vent and at $10-16^{\circ} \mathrm{E}$ on the Southwest Indian Ridge suggest that exothermic serpentinization reactions are insufficient to produce the required high-temperature fluid fluxes [Bach et al., 2002; German and Von Damm, 2003; Baker and German, 2004; Baker et al., 2004; German and Lin, 2004]. Thus, exothermic serpentinite reactions do not likely explain the anomalously young ages we observe over reasonable time scales.

\subsection{Off-Axis Magmatism}

[39] High-temperature $\left(>300^{\circ} \mathrm{C}\right)$ hydrothermal vent systems (e.g., TAG and Rainbow hydrothermal vent fields [e.g., Kleinrock and Humphris, 1996; Humphris and Cann, 2000; Allen and Seyfried, 2004; Seyfried et al., 2004]) have fluid temperatures similar to estimated temperatures of greenschist facies metamorphic assemblages that we find associated with transform-parallel and transformperpendicular faults on Atlantis Bank. In the case of the TAG and Rainbow vents, hydrothermal circulation is believed to be tectonically controlled by normal fault systems, and fed by episodic basaltic magmatism at depth [Humphris and Cann, 2000; Charlou et al., 2002; Douville et al., 2002].

Time scales for active venting in these systems are on the order of 1 to $10 \mathrm{ka}$ [Lalou et al., 1990, 1993; German and Parson, 1998; Humphris and Cann, 2000; Cave et al., 2002], which if analogous to Atlantis Bank, would result in complete reequilibration of the (U-Th)/He zircon system, as discussed above. Thus, these high-temperature magma-fed hydrothermal vent systems may be modern analogs to the systems that produced the anomalously young ages on Atlantis Bank.
[40] Modern high-temperature hydrothermal vents are located within or near the axial valley, where episodic basaltic magmatism can provide sufficient heat to drive hydrothermal circulation. In the case of Atlantis Bank, the young (U-Th)/He zircon ages require a source of heat $\left(>300^{\circ} \mathrm{C}\right)$ significantly off axis to explain their anomalous ages. One possibility is that transtension between 19.5 and $7.5 \mathrm{Ma}$ related to changes in the direction of plate motion [Baines et al., 2003] may have induced mantle upwelling and partial melting beneath the Atlantis II transform fault resulting in melt migration and magmatic underplating beneath Atlantis Bank [cf. Natland and Dick, 2002]. Numerical models and studies of other transform faults suggest that centers of oceanic transform faults may be warmer than normally assumed, and during periods of transtension may result in the local development of partial melts and intratransform spreading centers [Menard and Atwater, 1969; Lonsdale, 1989; Behn et al., 2007].

[41] Various observations of off-axis magmatism in the region support this leaky transform model. A present-day active volcanic edifice was observed along the eastern wall of the Atlantis II transform, $\sim 30 \mathrm{~km}$ south of the present-day ridge axis [Dick et al., 1991b; Kinoshita et al., 2001]. Diabase dikes were observed cutting the detachment fault surface on dive 645 during Jamstec MODE 2001 [Arai et al., 2001], suggesting post-detachment-faulting magmatism. On Shinkai dive 467, NW of Hole $735 \mathrm{~B}$ along the eastern wall of the Atlantis II transform at $32^{\circ} 38^{\prime} \mathrm{S}$ (Figure 1), a gently dipping diabase dike was observed filling a joint/fault which cuts a moderately north dipping mylonitic fabric [Kinoshita et al., 2001]. An anomalously young $\mathrm{Pb} / \mathrm{U}$ zircon age of $\sim 11.4 \mathrm{Ma}$ was obtained for a sample collected from the eastern flank of Atlantis Bank during Jamstec MODE 2001 dive 653 [Baines et al., 2009]. This sample is $\sim 1.1 \mathrm{Ma}$ younger that the sea surface magnetic age for the area where it is located [Baines et al., 2008] and on the basis of seafloor spreading rates during the formation of Atlantis Bank [Baines et al., 2008], it likely formed outside the rift valley. Last, fresh pillow basalt lavas with glassy margins collected from the detachment surface on the same dive.

[42] Basaltic underplating can also explain the young ages at the base of ODP Hole 735B, which do not show signs of extensive greenschist facies alteration. In the underplating model, these ages would be reset by conductive heating due to the intrusion of underplated magma at depth beneath 


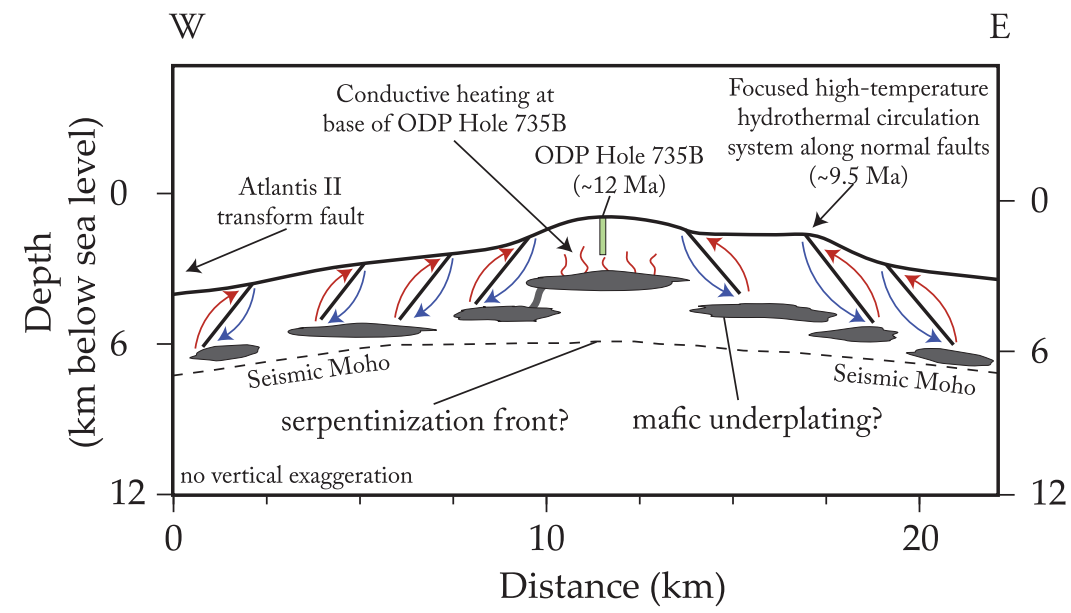

Figure 11. E-W oriented cross-sectional model (perpendicular to spreading direction) for the thermal evolution of Atlantis Bank. Mafic underplating beneath Atlantis Bank at $\sim 9.5$ Ma resulted in focused hydrothermal fluid flow along transform-parallel and transform-perpendicular faults. This circulation reset the (U-Th)/He zircon isotopic system. Fluid temperatures similar to modern high-temperature vent systems $\left(\geq 300^{\circ} \mathrm{C}\right)$ would result in complete reequilibration in $<1.5 \mathrm{ka}$. High-temperature fluid flow is supported by pervasive greenschist facies alteration in all surface samples in this study. Conductive reheating may explain the young ages at the base of ODP Hole 735 which do not show evidence for fluid alteration. Seismic Moho from Muller et al. [2000] is shown and may support crustal thickening due to mafic underplating at $\sim 9.5 \mathrm{Ma}$.

Hole $735 \mathrm{~B}$, rather than by advection of heat by hydrothermal circulation along faults.

[43] Analyses of seismic and gravity data suggests thick crust beneath Atlantis Bank, consistent with a model of mafic underplating [Muller et al., 1997, 2000]. These data indicate that the seismic Moho beneath Atlantis Bank is approximately $6 \mathrm{~km}$ deep which suggests anomalously thick crust compared to the average $3 \pm 1 \mathrm{~km}$ regional crustal thickness [Muller et al., 1997, 2000], a situation made even more acute if the $1.5-2.0 \mathrm{~km}$ of upper crust removed by detachment faulting is restored [Vanko and Stakes, 1991]. Muller et al. [1997] prefer to interpret the seismic Moho as a serpentinization front with the crust-mantle boundary at approximately $3 \mathrm{~km}$ depth. However, an alternative interpretation of these data is that the seismic Moho is indeed the petrological Moho [Muller et al., 1997], in which case we suggest that the thick crust may be the result of significant off-axis magmatic underplating. This underplating may have provided a source of heat for overlying tectonically controlled hydrothermal circulation systems, and may partly explain the anomalously high elevation of Atlantis Bank.

[44] One plausible model for the late stage development of Atlantis Bank is shown in Figure 11. This model assumes Atlantis Bank was subject to a period of off-axis magmatism as a consequence of transtension on the Atlantis II transform fault. Heat derived from this magmatism may have been supplemented by exothermic serpentinization reactions. These combined heat sources are inferred to have driven high-temperature $\left(>300^{\circ} \mathrm{C}\right)$ hydrothermal circulation along transform-parallel and transform-perpendicular faults. A major difference between this model and modern, structurally controlled high-temperature vent systems is that focused hydrothermal fluid flow at Atlantis Bank appears to have taken place well outside the axial valley. If this model for Atlantis Bank is correct, it may be applicable to other oceanic core complexes formed adjacent to transform faults and they may be subject to protracted cooling histories involving high-temperature hydrothermal circulation up to several million years off axis.

\section{Conclusions}

[45] Twenty-six new (U-Th)/He zircon ages from Atlantis Bank, Southwest Indian Ridge, indicate that the oceanic core complex initially cooled rapidly $(<1 \mathrm{Ma})$, yielding cooling rates $>1200^{\circ} \mathrm{C} /$ $\mathrm{Ma}$. These rates are consistent with other thermochronologic studies of Atlantis Bank as well as other thermochronologic and numerical models for the cooling of lower oceanic crust. The majority of our data $(>70 \%)$, however, show evidence for elevated temperature conditions (i.e., temperatures 
above the closure temperature of the (U-Th)/He zircon system $\left.\left(200^{\circ} \mathrm{C} \pm 15\right)\right)$ up to 3-4 Ma after igneous crystallization, well outside the axial ridge valley. Similar anomalously young ages are also recorded by zircon, sphene and apatite fission track data from ODP Hole 735B. These young ages are inconsistent with simple conductive cooling models for lower oceanic crust and suggest an off-axis thermal event. These samples are located near major faults, which postdate the formation of the core complex, and are metamorphosed at greenschist facies conditions. We interpret these anomalously young ages as recording high-temperature $\left(>300^{\circ} \mathrm{C}\right)$, focused hydrothermal fluid flow along transform-parallel and transform-perpendicular normal faults outside the axial ridge valley. We suggest that the heat source may have been off-axis basaltic underplating beneath Atlantis Bank related to a period of transtension along the Atlantis II transform fault related to a change in plate spreading direction. In addition, this magmatic event may be partially responsible for the anomalously high elevation of Atlantis Bank.

Appendix A: Additional Cooling Profiles and Detailed Rock Descriptions of (U-Th)/He Zircon Thermochronology Samples Collected
by Manned Submersible Dives on
Atlantis Bank, Southwest Indian Ridge

[46] Additional slow cooling profiles for samples collected on Atlantis Bank are shown in Figure A1.

[47] Sample 458-5 is a float sample collected at $4195 \mathrm{~m}$ below sea level (mbsl). The sample is a coarse-grained $(5-30 \mathrm{~mm})$ oxide gabbronorite impregnated by $5 \mathrm{~cm}$ thick medium-grained, sheared gabbro with recrystallized/albitized plagioclase.

[48] Sample 459-12 consists of oxide olivine gabbro collected from outcrop sample at 2294 mbsl. This sample is a medium- to coarse-grained protomylonite with large clinopyroxene "augen" surrounded by recrystallized plagioclase material. cut by dark amphibole-filled shear fractures. Plagioclase is altered to albite.

[49] Sample 460-15 consists of biotite hornblende oxide gabbro collected at $1640 \mathrm{mbsl}$ from talus debris near top of Atlantis Bank. Primary mineralogy consists of coarse-grained plagioclase and clinopyroxene altered to chlorite and actinolite. The sample is located $\sim 200 \mathrm{~m}$ above $40^{\circ} \mathrm{W}$ dipping normal fault.
[50] Sample 467-8 consists of fine- to mediumgrained hornblende gabbro collected on outcrop at $2526 \mathrm{mbsl}$. The sample is cut by amphibole and plagioclase filled fractures and primary mineralogy is altered to hornblende and chlorite. Further up slope, a gently dipping dike cuts a north dipping mylonitic fabric oriented at $010^{\circ} / 30^{\circ} \mathrm{W}$. The dike may have filled a joint or fault.

[51] Sample 172-18 consists of coarse-grained olivine oxide gabbro collected from outcrop at 3314 mbsl. The sample is $25 \%$ altered, with some semibrittle deformation. This sample is located approximately $300 \mathrm{~m}$ below the detachment fault surface (at $3040 \mathrm{mbsl}$ ) where massive outcrops of oxide gabbro are observed along steeply dipping $\mathrm{E}-\mathrm{W}$ and $\mathrm{N}-\mathrm{S}$ oriented joints and normal and strike-slip faults. Deformation fabrics in oriented samples from these outcrops indicate significant brittle deformation on steeply dipping faults. Cruise report observations indicate that many of the brittle fabrics are either crosscut or synchronous with high-temperature hydrothermal alteration [Arai et al., 2001]. Upslope from 172 to 18 approximately $300 \mathrm{~m}$, sample 172-25 (see Figure 2) is an ultramylonite overprinted by cataclasistic fabric associated with a fault surface oriented $090^{\circ} / 70^{\circ} \mathrm{N}$. The sample is characterized by epidote-cemented brec$\mathrm{cia} /$ vein fill, indicating high-temperature $\left(\sim 300^{\circ} \mathrm{C}\right)$ hydrothermal fluid up flow on this fault and possible others in the area.

[52] Sample 644-12 consists of medium- to coarsegrained oxide gabbronorite collected on outcrop along a fault scarp 1979 mbsl. The fault scarp is $>100 \mathrm{~m}$ high with striae indicating sinistral oblique slip. The sample is $90 \%$ altered to chlorite, actinolite and hornblende. Hornblende veins crosscut the protomylonitic to mylonitic deformation fabric shown in Figure A2.

[53] Sample 645-11/12 consists of talc-chlorite schist and diabase collected on the detachment fault surface at $2191 \mathrm{mbsf}$. The fine-grained diabase intrudes the talc-chlorite schist.

[54] Sample 647-5/6 consists of hornblende olivine gabbro and hornblende olivine oxide gabbro collected on outcrop at 1946 mbsl. The sample has a protomylonitic to mylonitic fabric which is cut by $1 \mathrm{~mm}$ hornblende veins. The sample was collected adjacent to subvertical joints orientated at $\sim 300^{\circ}$.

[55] Sample 648-20 consists of medium-grained mylonitic gabbro collected at $1752 \mathrm{mbsl}$ along a $>1 \mathrm{~km} \mathrm{~N}-\mathrm{S}$ striking fault scarp $\left(000^{\circ} / 50^{\circ} \mathrm{E}\right)$. The 
Slow Cooling Profiles
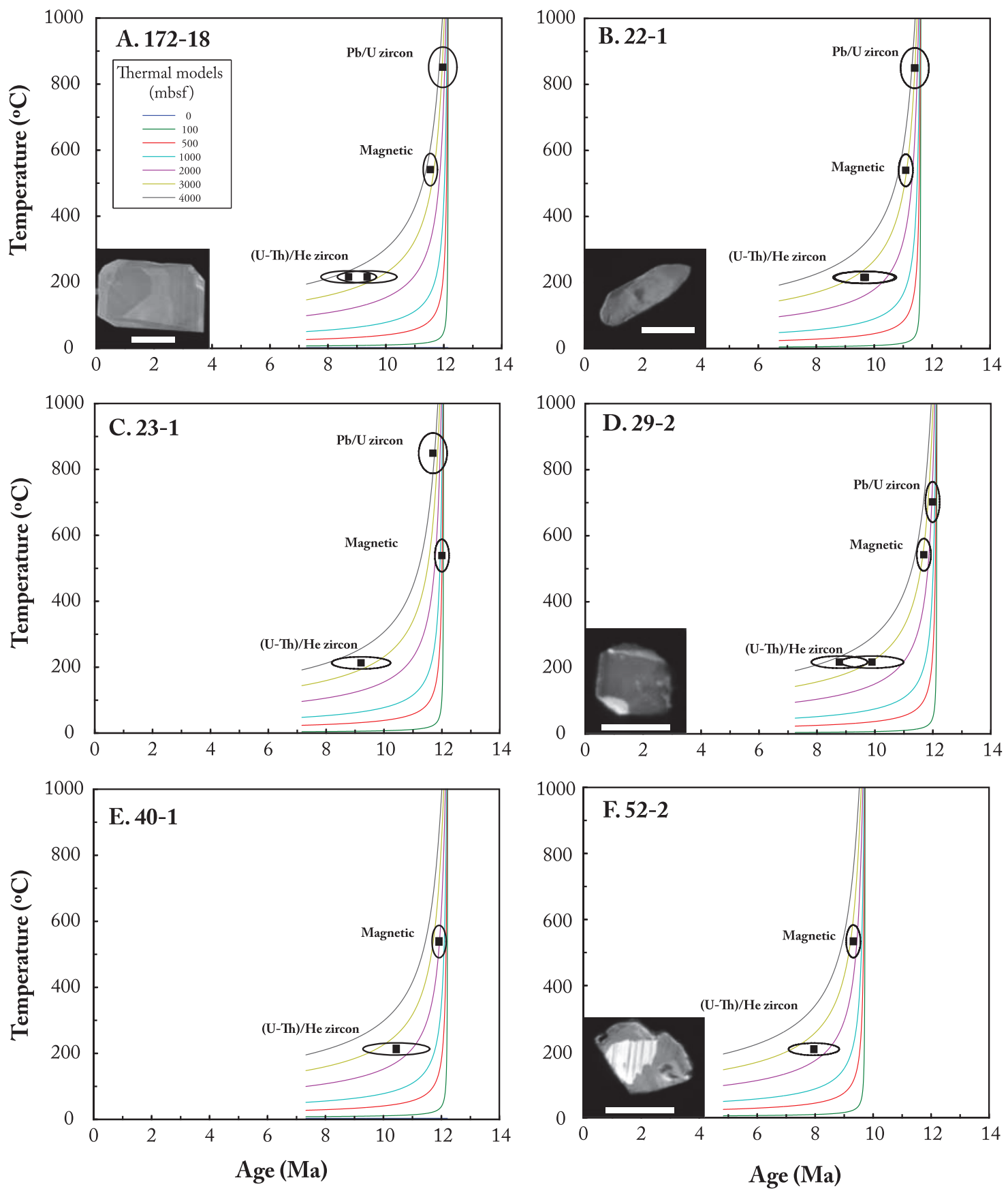

Figure A1. Cooling profiles for samples collected on Atlantis Bank showing slower cooling profiles. Thermal models for conductive cooling of oceanic lithosphere at various constant depths are shown by colored curves. Model cooling curves were calculated using a full-spreading rate of $14 \mathrm{~mm} / \mathrm{a}$, a lithospheric thickness of $100 \mathrm{~km}$, a mantle potential temperature of $1330^{\circ} \mathrm{C}$, thermal conductivity of $3.2 \mathrm{~W} / \mathrm{m} / \mathrm{K}$, density of $3300 \mathrm{~kg} / \mathrm{m}^{3}$, and specific heat capacity of $1170 \mathrm{~J} / \mathrm{kg} / \mathrm{K}$. 

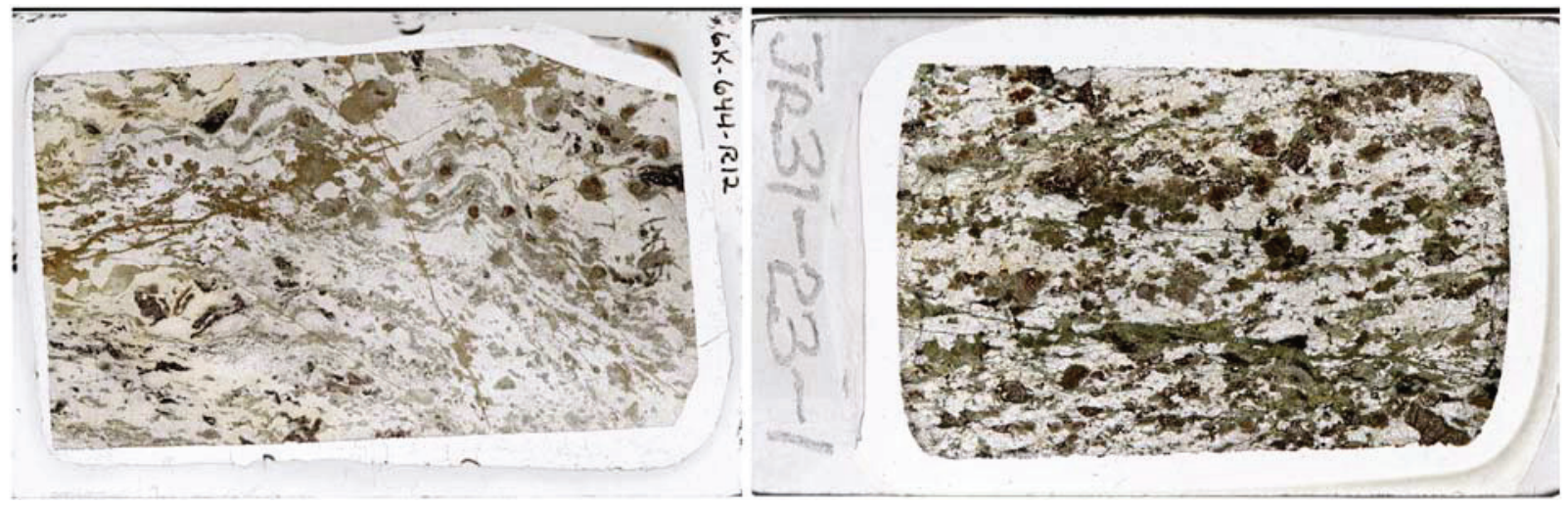

Figure A2. Large-format thin section scans in plain polarized light for two samples along the eastern fault scarp. Both of these samples have high-temperature deformational fabrics overprinted by greenschist facies metamorphism in association with brittle deformation. Crosscutting veins in sample 644-12 are filled with green hornblende.

sample is moderately altered to hornblende and serpentine and is cut by small white fractures.

[56] Sample 650-1/2 consists of olivine hornblende oxide gabbro and olivine oxide gabbronorite collected from outcrop along an E-W striking, north dipping fault surface at $2488 \mathrm{mbsl}$. The oxide olivine gabbronorite is approximately 58\% altered in association with minor brittle deformation. Amphibole, chlorite and smectite veins crosscut the rock.

[57] Sample 651-1 consists of medium- to coarsegrained mylonitic oxide gabbro collected from float at $4306 \mathrm{mbsl}$. The sample has a minor cataclastic overprint. Dikes were observed approximately $100 \mathrm{~m}$ upslope at $4209 \mathrm{mbsl}$.

\section{Acknowledgments}

[58] We thank Henry Dick for access to samples from JAMSTEC and James Clark Ross cruises and for helpful discussions related to the geology of Atlantis Bank. Funding for this work was provided by NSF OCE grant 0352054 to M. J. Cheadle and B. E. John and a Wyoming NASA space grant to J. J. Schwartz. We wish to acknowledge constructive journal review by Andrew Fisher. We thank Stefan Nicolescu for analytical assistance. A.G.B.'s contribution makes TRaX record 016 .

\section{References}

Allen, D. E., and W. E. Seyfried (2004), Serpentinization and heat generation: Constraints from Lost City and Rainbow hydrothermal systemsGeochim. Cosmochim. Acta, 68(6), 1347-1354, doi:10.1016/j.gca.2003.09.003.

Allerton, S., and C. J. MacLeod (1998), Fault-controlled magma transport through mantle lithosphere at slow-spreading ridges, in Modern Ocean Floor Processes and the Geological Record, edited by R. A. Mills and K. Harrison, pp. 2942, Geol. Soc., London.
Alt, J. C., and W. Bach (2006), Oxygen isotope composition of a section of lower oceanic crust, ODP Hole 735B, Geochem. Geophys. Geosyst., 7, Q12008, doi:10.1029/2006GC001385.

Alt, J. C., et al. (2002), Low-grade hydrothermal alteration of uplifted lower oceanic crust, Hole 735B: Mineralogy and isotope geochemistry, Proc. Ocean Drill. Program Sci. Results [CD-ROM], 176.

Arai, S., H. J. B. Dick, and S. S. Party (2001), MODE 2000 Leg 6 Cruise Report, Jpn. Agency for Mar.-Earth Sci. and Technol., Yokosuka, Japan.

Bach, W., J. C. Alt, Y. Niu, S. E. Humphris, J. Erzinger, and H. J. B. Dick (2001), The geochemical consequences of latestage low-grade alteration of lower ocean crust at the SW Indian Ridge: Results from ODP Hole 735B (Leg 176), Geochim. Cosmochim. Acta, 65(19), 3267-3287, doi:10.1016/S0016-7037(01)00677-9.

Bach, W., N. R. Banerjee, H. J. B. Dick, and E. T. Baker (2002), Discovery of ancient and active hydrothermal systems along the ultra-slow spreading Southwest Indian Ridge $10^{\circ}-16^{\circ} \mathrm{E}$, Geochem. Geophys. Geosyst., 3(7), 1044, doi:10.1029/2001GC000279.

Baines, A. G. (2006), Geodynamic investigation of ultra-slow spreading oceanic lithosphere: Atlantis Bank and vicinity, SW Indian Ridge, Ph.D. dissertation, 213 pp., Univ. of Wyo., Laramie.

Baines, A. G., M. J. Cheadle, H. J. B. Dick, A. Hosford Scheirer, B. E. John, N. J. Kusznir, and T. Matsumoto (2003), A mechanism for generating the anomalous uplift of oceanic core-complexes: Atlantis Bank, SW Indian Ridge, Geology, 31(12), 1105-1108, doi:10.1130/G19829.1.

Baines, A. G., M. J. Cheadle, H. J. B. Dick, A. Hosford Scheirer, B. E. John, N. J. Kusznir, and T. Matsumoto (2007), Evolution of the Southwest Indian Ridge from $55^{\circ} 45^{\prime} \mathrm{E}$ to $62^{\circ} \mathrm{E}$ : Changes in plate-boundary geometry since $26 \mathrm{Ma}$, Geochem. Geophys. Geosyst., 8, Q06022, doi:10.1029/2006GC001559.

Baines, A. G., M. J. Cheadle, B. E. John, and J. J. Schwartz (2008), The rate of oceanic detachment faulting at Atlantis Bank, SW Indian Ridge, Earth Planet. Sci. Lett., 273, 105114, doi:10.1016/j.epsl.2008.1006.1013.

Baines, A. G., M. J. Cheadle, B. John, C. B. Grimes, J. J. Schwartz, and J. L. Wooden (2009), SHRIMP $\mathrm{Pb} / \mathrm{U}$ zircon ages constrain gabbroic crustal accretion at the ultraslow- 
spreading Southwest Indian Ridge, Earth Planet. Sci. Lett., in press.

Baker, E., and C. R. German (2004), On the global distribution of hydrothermal vent fields, in Mid-Ocean Ridges: Hydrothermal Interactions Between the Lithosphere and Oceans, Geophys. Monogr. Ser., vol. 148, edited by C. R. German, J. Lin, and L. M. Parson, pp. 245-266, AGU, Washington, D. C.

Baker, E. T., H. N. Edmonds, P. J. Michael, W. Bach, H. J. B. Dick, J. Snow, S. L. Walker, and C. H. Langmuir (2004), Hydrothermal venting in magma deserts: The ultraslowspreading Gakkel and Southwest Indian Ridges, Geochem. Geophys. Geosyst., 5, Q08002, doi:10.1029/2004GC000712.

Behn, M. D., M. S. Boettcher, and G. Hirth (2007), Thermal structure of oceanic transform faults, Geology, 35(4), 307310, doi:10.1130/G23112A.1.

Blackman, D. K., et al. (2004), Geology of the Atlantis Massif (Mid-Atlantic Ridge, $30^{\circ} \mathrm{N}$ ): Implications for the evolution of an ultramafic oceanic core complex, Mar. Geophys. Res., 23(5-6), 443-469.

Blackman, D. K., B. Ildefonse, B. E. John, Y. Ohara, D. J. Miller, C. J. MacLeod, and T. E. Scientists (2006), Proceedings of the Integrated Ocean Drilling Program, vol. 304/305, doi:10.2204/iodp.proc.304305, Ocean Drill. Program, College Station, Tex.

Buck, W. R., L. L. Lavier, and A. N. B. Poliakov (2005), Modes of faulting at mid-ocean ridges, Nature, 434(7034), 719-723, doi:10.1038/nature03358.

Cann, J. R., D. K. Blackman, D. K. Smith, E. McAllister, B. Janssen, S. Mello, E. Avgerinos, A. R. Pascoe, and J. Escartin (1997), Corrugated slip surfaces formed at ridgetransform intersections on the Mid-Atlantic Ridge, 385(6614), $329-332$.

Cannat, M., et al. (1991), Plastic deformation at an oceanic spreading ridge; a microstructural study of the Site 735 gabbros (Southwest Indian Ocean), Proc. Ocean Drill. Program Sci. Results, 118, 399-408.

Casey, J. F., , and D. J. Miller (Eds.) (2007), Proceedings of the Ocean Drilling Program, Scientific Results, doi:10.2973/ odp.proc.sr.2179.2007, Ocean Drill. Program, College Station, Tex.

Cave, R. R., C. R. German, J. Thomson, and R. W. Nesbitt (2002), Fluxes to sediments underlying the Rainbow hydrothermal plume at $36^{\circ} 14^{\prime} \mathrm{N}$ on the Mid-Atlantic Ridge, Geochim. Cosmochim. Acta, 66(11), 1905-1923.

Charlou, J. L., J. P. Donval, Y. Fouquet, P. Jean-Baptiste, and N. Holm (2002), Geochemistry of high $\mathrm{H}_{2}$ and $\mathrm{CH}_{4}$ vent fluids issuing from ultramafic rocks at the Rainbow hydrothermal field $\left(36^{\circ} 14^{\prime} \mathrm{N}, \mathrm{MAR}\right)$, Chem. Geol., 191(4), 345359, doi:10.1016/S0009-2541(02)00134-1.

Coogan, L. A. (2005), Cooling rate constraints on accretion of the lower oceanic crust, Eos Trans. $A G U, 86(52)$, Fall Meet. Suppl., Abstract T32A-08.

Coogan, L. A., G. R. T. Jenkin, and R. N. Wilson (2002), Constraining the cooling rate of the lower oceanic crust: A new approach applied to the Oman ophiolite, Earth Planet. Sci. Lett., 199, 127-146, doi:10.1016/S0012$821 \mathrm{X}(02) 00554-\mathrm{X}$.

Coogan, L. A., K. A. Howard, K. M. Gillis, M. J. Bickle, H. Chapman, A. J. Boyce, G. R. T. Jenkin, and R. N. Wilson (2006), Chemical and thermal constraints on focussed fluid flow in the lower oceanic crust, Am. J. Sci., 306(6), 389427, doi:10.2475/06.2006.01.

Coogan, L. A., G. R. T. Jenkin, and R. N. Wilson (2007), Contrasting cooling rates in the lower oceanic crust at fast- and slow-spreading ridges revealed by geospeedometry, J. Petrol., 48, 2211-2231, doi:10.1093/petrology/egm057.

Crank, J. (1975), The Mathematics of Diffusion, 424 pp., Clarendon, Oxford, U. K.

Dick, H. J. B., et al. (1991a), Lithostratigraphic evolution of an in-situ section of oceanic layer 3, Proc. Ocean Drill. Program Sci. Results, 118, 439-538.

Dick, H. J. B., H. Schouten, P. S. Meyer, D. G. Gallo, H. Bergh, R. Tyce, P. Patriat, K. T. M. Johnson, J. E. Snow, and A. Fisher (1991b), Tectonic evolution of the Atlantis II fracture zone, Proc. Ocean Drill. Program Sci. Results, 118, $359-398$.

Dick, H. J. B., J. H. Natland, D. J. Miller, and S. S. Party (1999), Proceedings of the Ocean Drilling Program, Initial Report Leg 176, Ocean Drill. Program, College Station, Tex.

Dick, H. J. B., et al. (2000), A long in situ section of the lower ocean crust; results of ODP Leg 176 drilling at the Southwest Indian Ridge, Earth Planet. Sci. Lett., 179(1), 31-51, doi:10.1016/S0012-821X(00)00102-3.

Dick, H. J. B., J. Lin, and H. Schouten (2003), An ultraslowspreading class of ocean ridge, Nature, 426, 405-408, doi:10.1038/nature02128.

Dodson, M. H. (1973), Closure temperature in cooling geochronological and petrological systemsContrib. Mineral. Petrol., 40(3), 259-274, doi:10.1007/BF00373790.

Douville, E., J. L. Charlou, E. H. Oelkers, P. Bienvenu, C. F. Jove Colon, J. P. Donval, Y. Fouquet, D. Prieur, and P. Appriou (2002), The Rainbow Vent fluids $\left(36^{\circ} 14^{\prime} \mathrm{N}\right.$, MAR); the influence of ultramafic rocks and phase separation on trace metal content in Mid-Atlantic Ridge hydrothermal fluids, Chem. Geol., 184(1-2), 37-48, doi:10.1016/ S0009-2541(01)00351-5.

Dunn, R. A., D. R. Toomey, and S. C. Solomon (2000), Threedimensional seismic structure and physical properties of the crust and shallow mantle beneath the East Pacific Rise at $9^{\circ} 30^{\prime}$ N, J. Geophys. Res., 105(B10), 23,537-523,555.

Farley, K. A. (2007), He diffusion systematics in minerals: Evidence from synthetic monazite and zircon structure phosphates, Geochim. Cosmochim. Acta, 71(16), 4015-4024, doi:10.1016/j.gca.2007.05.022.

Farley, K. A., R. A. Wolf, and L. T. Silver (1996), The effects of long alpha-stopping distances on (U-Th)/He ages, Geochim. Cosmochim. Acta, 60(21), 4223-4229.

Fisher, A. T., and K. Becker (2000), Channelized fluid flow in oceanic crust reconciles heat-flow and permeability data, Nature, 403, 71-74, doi:10.1038/47463.

Früh-Green, G. L., D. S. Kelley, S. M. Bernasconi, J. A. Karson, K. A. Ludwig, D. A. Butterfield, C. Boschi, and G. Proskurowski (2003), 30,000 years of hydrothermal activity at the Lost City vent field, Science, 301(5632), 495-498, doi:10.1126/science.1085582.

Gao, Y., J. Hoefs, R. Przybilla, and J. E. Snow (2006), A complete oxygen isotope profile through the lower oceanic crust, ODP Hole 735B, Chem. Geol., 233(3-4), 217-234, doi:10.1016/j.chemgeo.2006.03.005.

German, C. R., and J. Lin (2004), The thermal structure of the oceanic crust, ridge-spreading and hydrothermal circulation: How well do we understand their inter-connections?, in MidOcean Ridges: Hydrothermal Interactions Between the Lithosphere and Oceans, Geophys. Monogr. Ser., vol. 148, edited by C. R. German, J. Lin, and L. M. Parson, pp. 1-18, AGU, Washington, D. C.

German, C. R., and L. M. Parson (1998), Distributions of hydrothermal activity along the Mid-Atlantic Ridge: Interplay of magmatic and tectonic controls, Earth Planet. Sci. 
Lett., 160(3-4), 327-341, doi:10.1016/S0012821X(98)00093-4.

German, C. R., and K. L. Von Damm (2003), Hydrothermal processes, in Treatise on Geochemistry, edited by K. K. Turekian and H. D. Holland, pp. 181-222, Elsevier, Oxford, U. K.

Grimes, C. B., B. E. John, P. B. Kelemen, F. K. Mazdab, J. L. Wooden, M. J. Cheadle, K. Hanghoj, and J. J. Schwartz (2007), Trace element chemistry of zircons from oceanic crust: A method for distinguishing detrital zircon provenance, Geology, 35(7), 643-646, doi:10.1130/G23603A.1.

Grimes, C. B., B. E. John, M. J. Cheadle, and J. L. Wooden (2008), Protracted construction of gabbroic crust at a slow spreading ridge: Constraints from $206 \mathrm{~Pb} / 238 \mathrm{U}$ zircon ages from Atlantis Massif and IODP Hole U1309D $\left(30^{\circ} \mathrm{N}\right.$, MAR), Geochem. Geophys. Geosyst., 9, Q08012, doi:10.1029/2008GC002063.

Henstock, T. J., A. W. Woods, and R. S. White (1993), The accretion of oceanic crust by episodic sill intrusion, J. Geophys. Res., 98, 4143-4161, doi:10.1029/92JB02661.

Hosford, A., M. A. Tivey, T. Matsumoto, H. J. B. Dick, H. Schouten, and H. Kinoshita (2003), Crustal magnetization and accretion at the Southwest Indian Ridge near the Atlantis II fracture zone, 0-25 Ma, J. Geophys. Res., 108(B3), 2169, doi:10.1029/2001JB000604.

Hourigan, J. K., P. W. Reiners, and M. T. Brandon (2005), U/Th zonation-dependent alpha-ejection in (U-Th)/He chronometry, Geochim. Cosmochim. Acta, 69(13), 3349-3365, doi:10.1016/j.gca.2005.01.024.

Humphris, S. E., and J. R. Cann (2000), Constraints on the energy and chemical balances of the modern TAG and ancient Cyprus seafloor sulfide deposits, J. Geophys. Res., 105(B12), 28,477-28,488.

Humphris, S. E., R. A. Zierenberg, L. S. Mullineaux, and R. E. Thompson (1995), Seafloor Hydrothermal Systems: Physical Chemical, Biologic and Geological Interactions, Geophys. Monogr. Ser., vol. 91, 466 pp., AGU, Washington, D. C.

IODP Expeditions 304 and 305 Scientists (2005), IODP Expeditions 304 and 305: Oceanic core complex formation, Atlantis Massif, Sci. Drill., 1, 28-31, doi:10.22 04/ iodp.sd.1.05.2005.

John, B. E., D. A. Foster, J. M. Murphy, M. J. Cheadle, A. G. Baines, C. M. Fanning, and P. Copeland (2004), Determining the cooling history of in situ lower oceanic crust-Atlantis Bank, SW Indian Ridge, Earth Planet. Sci. Lett., 222, 145-160, doi:10.1016/j.eps1.2004.02.014.

Kelley, D. S., and G. L. Früh-Green (2001), Volatile lines of descent in submarine plutonic environments: Insights from stable isotope and fluid inclusion analyses, Geochim. Cosmochim. Acta, 65, 3325-3346, doi:10.1016/S00167037(01)00667-6.

Kinoshita, H., H. J. B. Dick, and Y. Party (2001), $M O D E$ '98 Leg 4 Cruise Report, 221 pp., Jpn. Agency for Mar.-Earth Sci. and Technol., Yokosuka, Japan.

Kleinrock, M. C., and S. E. Humphris (1996), Structural controls on seafloor hydrothermal activity at the TAG active mound, Nature, 382, 149-153, doi:10.1038/382149a0.

Lalou, C., G. Thompson, M. Arnold, E. Brichet, E. R. M. Druffel, and P. A. Rona (1990), Geochronology of TAG and Snakepit hydrothermal fields, Mid-Atlantic Ridge: Witness to a long and complex hydrothermal history, Earth Planet. Sci. Lett., 97(1-2), 113-128, doi:10.1016/ 0012-821X(90)90103-5.

Lalou, C., J.-L. Reyss, E. Brichet, M. Arnold, G. Thompson, Y. Fouquet, and P. A. Rona (1993), New age data for MidAtlantic Ridge hydrothermal sites: TAG and Snakepit chron- ology revisited, J. Geophys. Res., 98(B6), 9705-9713, doi:10.1029/92JB01898.

Lavier, L. L., W. R. Buck, and A. N. B. Poliakov (1999), Self-consistent rolling-hinge model for the evolution of large-offset low-angle normal faults, Geology, 27(12), 1127-1130, doi:10.1130/0091-7613(1999)027<1127: $\mathrm{SCRHMF}>2.3 . \mathrm{CO} ; 2$.

Lavier, L. L., W. R. Buck, and A. N. B. Poliakov (2000), Factors controlling normal fault offset in an ideal brittle layer, J. Geophys. Res., 105(B10), 23,431-23,442.

Lister, C. R. B. (1974), On the penetration of water into hot rock, Geophys. J. R. Astron. Soc., 39(3), 465-509.

Lister, C. R. B. (1983), The basic physics of water penetration into hot rock, in Hydrothermal Processes at Seafloor Spreading Centers, pp. 141-168, Plenum, New York.

Lonsdale, P. (1989), Segmentation of the Pacific-Nazca spreading center, $1^{\circ} \mathrm{N}-20^{\circ} \mathrm{S}, J$. Geophys. Res., 94(B9), $12,197-12,225$.

Maclennan, J., T. Hulme, and S. C. Singh (2005), Cooling of the lower oceanic crust, Geology, 33(5), 357-366, doi: $10.1130 / \mathrm{G} 21207.1$.

MacLeod, C. J., et al. (2002), Direct geological evidence for oceanic detachment faulting: The Mid-Atlantic Ridge, $15^{\circ} 45^{\prime} \mathrm{N}$, Geology, 30(10), 879-882, doi:10.1130/00917613(2002)030<0879:DGEFOD>2.0.CO;2.

Manning, C. E., C. MacLeod, and P. E. Weston (2000), Lowercrustal cracking front at fast-spreading ridges: Evidence from the East Pacific Rise and the Oman ophiolite, in Ophiolites and Ocean Crust: New Insights From Field Studies and Ocean Drilling Program, edited by Y. Dilek, E. Moores, D. Elthon, and A. Nicolas, Spec. Pap. Geol. Soc. Am., $349,261-272$

Matsumoto, T., H. J. B. Dick, and S. S. Party (2002), Preliminary Report (ABCDE) Yokosuka/Shinkai 6500 YK01-14 Cruise Results, 463 pp., Jpn. Agency for Mar.-Earth Sci. and Technol., Yokosuka, Japan.

McCaig, A. M., R. A. Cliff, J. Escartin, A. E. Fallick, and C. J. MacLeod (2007), Oceanic detachment faults focus very large volumes of black smoker fluids, Geology, 35(10), 935-938, doi:10.1130/G23657A.1.

McKenzie, D. (1967), Some remarks on heat flow and gravity anomalies, J. Geophys. Res., 72, 6261-6273, doi:10.1029/ JZ072i024p06261.

Mehl, L., and G. Hirth (2008), Plagioclase preferred orientation in layered mylonites: Evaluation of flow laws for the lower crust, J. Geophys. Res., 113, B05202, doi:10.1029/ 2007JB005075.

Menard, H. W., and T. Atwater (1969), Origin of fracture zone topography, Nature, 222(5198), 1037-1040, doi:10.1038/ $2221037 \mathrm{a} 0$.

Mével, C., and M. Cannat (1991), Lithospheric stretching and hydrothermal processes in oceanic gabbros from slowspreading ridges, Petrol. Struct. Geol., 5, 293-312.

Miranda, E. A. (2006), Structural Development of the Atlantis Bank Oceanic Detachment Fault System, Southwest Indian Ridge, 457 pp., Univ. of Wyo., Laramie.

Muller, M. R., C. J. Robinson, T. A. Minshull, R. S. White, and M. J. Bickle (1997), Thin crust beneath ocean drilling program borehole $735 \mathrm{~B}$ at the Southwest Indian Ridge, Earth Planet. Sci. Lett., 148, 93-107, doi:10.1016/S0012821X(97)00030-7.

Muller, M. R., T. A. Minshull, and R. S. White (2000), Crustal structure of the Southwest Indian Ridge at the Atlantis II Fracture Zone, J. Geophys. Res., 105(B11), 25,80925,828, doi:10.1029/2000JB900262. 
Natland, J. H., and H. J. B. Dick (2001), Formation of the lower ocean crust and the crystallization of gabbroic cumulates at a very slowly spreading ridge, J. Volcanol. Geotherm. Res., 110(3-4), 191-233, doi:10.1016/S0377-0273(01) 00211-6.

Natland, J. H., and H. J. B. Dick (2002), Stratigraphy and composition of gabbros drilled in Ocean Drilling Program Hole 735B, Southwest Indian Ridge: A synthesis of geochemical data, Proc. Ocean Drill. Program Sci. Results [CD-ROM], 176.

Pettigrew, T. J., et al. (1999), Leg 179 summary, Proc. Ocean Drill. Program Initial Rep. [online], 179. (Available at http:// www-odp.tamu.edu/publications/179_IR/chap_01/ chap_01.htm)

Phipps Morgan, J., and Y. J. Chen (1993), The genesis of oceanic crust: Magma injection, hydrothermal circulation, and crustal flow, J. Geophys. Res., 98, 6283-6297, doi:10.1029/92JB02650.

Reiners, P. W. (2005), Zircon (U-Th)/He thermochronometry, in Low Temperature Thermochronology: Techniques, Interpretations and Applications, Rev. Mineral. and Geochem., vol. 58, edited by P. W. Reiners and T. Ehlers, pp. 151179, Mineral. Soc. of Am., Chantilly, Va.

Reiners, P. W., T. L. Spell, S. Nicolescu, and K. A. Zanetti (2004), Zircon (U-Th)/He thermochronometry: He diffusion and comparisons with ${ }^{40} \mathrm{Ar} /{ }^{39} \mathrm{Ar}$ dating, Geochim. Cosmochim. Acta, 68(8), 1857-1887, doi:10.1016/j.gca.2003. 10.021.

Reiners, P. W., S. N. Thomson, D. McPhillips, R. A. Donelick, and J. J. Roering (2007), Wildfire thermochronology and the fate and transport of apatite in hillslope and fluvial environments, J. Geophys. Res., 112, F04001, doi:10.1029/ 2007JF000759.

Robinson, P. T., et al. (1991), Metamorphism and alteration in oceanic layer 3: Hole 735B, Proc. Ocean Drill. Program Sci. Results, 118, 541-562.

Robinson, P. T., et al. (2000), Lower oceanic crust formed at an ultra-slow-spreading ridge: Ocean Drilling Program Hole 735B, Southwest Indian Ridge, Spec. Pap. Geol. Soc. Am., $349,75-86$

Robinson, P. T., et al. (2002), The composition and origin of igneous and hydrothermal veins in the lower ocean crust; ODP Hole 735B, Southwest Indian Ridge, Proc. Ocean Drill. Program Sci. Results [CD-ROM], 176, 66 pp.

Schärer, U. (1984), The effect of initial 230Th disequilibrium on young U-Pb ages: The Makalu case, Himalaya, Earth
Planet. Sci. Lett., 67, 191-204, doi:10.1016/0012821X(84)90114-6.

Schroeder, T., and B. E. John (2004), Strain localization on an oceanic detachment fault system, Atlantis Massif, $30^{\circ} \mathrm{N}$, Mid-Atlantic Ridge, Geochem. Geophys. Geosyst., 5, Q11007, doi:10.1029/2004GC000728.

Schwartz, J. J., B. E. John, M. J. Cheadle, E. A. Miranda, C. B. Grimes, J. L. Wooden, and H. J. B. Dick (2005), Dating the growth of oceanic crust at a slow-spreading ridge, Science, 310(5748), 654-657, doi:10.1126/science.1116349.

Seyfried, W. E., D. I. Foustoukos, and D. E. Allen (2004), Ultramafic-hosted hydrothermal systems at mid-ocean ridges: Chemical and physical controls on $\mathrm{pH}$, redox carbon reduction reactions, in Mid-Ocean Ridges: Hydrothermal Interactions Between the Lithosphere and Oceans, Geophys. Monogr. Ser., vol. 148, edited by C. R. German, J. Lin, and K. M. Parsons, pp. 267-284, AGU, Washington, D. C.

Small, C. (1998), Global systematics of mid-ocean ridge morphology, in Faulting and Magmatism at Mid-Ocean Ridges, Geophys. Monogr. Ser., vol. 106, edited by W. R. Buck et al., pp. 1-26, AGU, Washington, D. C.

Stakes, D., C. Mevel, M. Cannat, and T. Chaput (1991), Metamorphic stratigraphy of Hole 735B, Proc. Ocean Drill. Program Sci. Results, 118, 153-180.

Tucholke, B. E., and J. Lin (1994), A geological model for the structure of ridge segments in slow spreading ocean crust, J. Geophys. Res., 99(B6), 11,937-11,958, doi:10.1029/ 94JB00338.

Tucholke, B. E., J. Lin, and M. C. Kleinrock (1998), Megamullions and mullion structure defining oceanic metamorphic core complexes on the Mid-Atlantic Ridge, J. Geophys. Res., 103(B5), 9857-9866, doi:10.1029/ 98JB00167.

Tucholke, B. E., M. D. Behn, W. R. Buck, and J. Lin (2008), Role of melt supply in oceanic detachment faulting and formation of megamullions, Geology, 36(6), 455-458, doi:10.1130/G24639A.

Vanko, D. A., and D. S. Stakes (1991), Fluids in oceanic layer 3: Evidence from veined rocks, Hole 735B, Southwest Indian Ridge, Proc. Ocean Drill. Program Sci. Results, 118, $181-215$.

Wetzel, L. R., J. P. Raffensperger, and E. L. Shock (2001), Predictions of hydrothermal alteration within near-ridge oceanic crust from coordinated geochemical and fluid flow models, J. Volcanol. Geotherm. Res., 110, 319-342, doi:10.1016/S0377-0273(01)00215-3. 